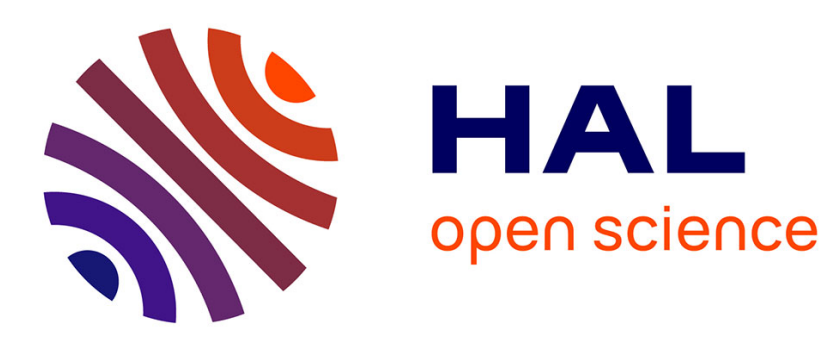

\title{
Evolution of the Himalaya since Miocene time: isotopic and sedimentological evidence from the Bengal Fan
}

Christian France-Lanord, Louis Derry, Annie Michard

\section{To cite this version:}

Christian France-Lanord, Louis Derry, Annie Michard. Evolution of the Himalaya since Miocene time: isotopic and sedimentological evidence from the Bengal Fan. The Geological Society, London, Special Publications, 1993, 74 (1), pp.603-621. 10.1144/gsl.sp.1993.074.01.40 . hal-02153142

\section{HAL Id: hal-02153142 \\ https://hal.science/hal-02153142}

Submitted on 23 Oct 2019

HAL is a multi-disciplinary open access archive for the deposit and dissemination of scientific research documents, whether they are published or not. The documents may come from teaching and research institutions in France or abroad, or from public or private research centers.
L'archive ouverte pluridisciplinaire HAL, est destinée au dépôt et à la diffusion de documents scientifiques de niveau recherche, publiés ou non, émanant des établissements d'enseignement et de recherche français ou étrangers, des laboratoires publics ou privés. 
France-Lanord, C., Derry, L. A., \& Michard, A. (1993). Evolution of the Himalaya since Miocene time: isotopic and sedimentological evidence from the Bengal Fan. Geological Society, London, Special Publications, 74(1), 603-621. http://doi.org/10.1144/gsl.sp.1993.074.01.40

Evolution of the Himalaya since Miocene time:

Isotopic and sedimentologic evidence from the Bengal Fan

Christian France-Lanord1, Louis Derry1, \& Annie Michard2

1: CRPG-CNRS, BP 20, 54501 Vandoeuvre les Nancy - France

2: LGE-CNRS, Université St Jérôme, CO 431, 13397 Marseille - France

Abstract: We report $\mathrm{Sr}, \mathrm{Nd}, \mathrm{O}$, and $\mathrm{H}$ isotopic data and clay mineral abundances for sediments recovered in ODP Leg 116 cores from the Bengal Fan at $1^{\circ} \mathrm{S}$. The samples studied cover the period between ca. $17 \mathrm{Ma}$ and the present. We also present new and compiled data on the isotopic compositions of potential source regions for the Bengal Fan sediments. eNd(0) values in the Bengal Fan sediments (all samples) define a narrow range about -16.0 . $87 \mathrm{Sr} / 86 \mathrm{Sr}$ values (all samples) are also in a narrow range near $0.741 . \mathrm{d} 18 \mathrm{O}$ values in quartz separates define a narrow range at $+12.8 \pm 0.5 \%$. Coarse biotite-chlorite separates give $\mathrm{d} 18 \mathrm{O}=3.6-5.6 \%$. Combined $\mathrm{d} 18 \mathrm{O}$ values of quartz and biotites indicate a metamorphic source. Clay mineral abundances define two clay facies: an illite-chlorite rich assemblage (IC) and a smectite-kaolinite rich assemblage (SK). $\mathrm{d} 18 \mathrm{O}$ in the IC clay fractions is $11.5-15 \%$, while SK clays are 18.2 $22.6 \%$. The narrow range of isotopic values throughout the deposition history implies that the source of the Bengal Fan sediments has not changed since the early Miocene, despite changes in sedimentation rate, sedimentary facies, tectonic history and climactic regime. The difference between $\mathrm{d} 18 \mathrm{O}$ in the IC and SK clay fractions represents different alteration histories of the same source material. The SK clays appear to have been altered at low T in the Indo-Gangetic Plain, while the IC clays and coarse fractions preserve metamorphic signatures. The narrow range of the $\mathrm{Sr}$ values, despite wide variation in $\mathrm{Rb} / \mathrm{Sr}$ ratio, also argues for a source that underwent isotopic homogenization shortly before erosion and deposition of the sediment. The source that meets these criteria is the High Himalayan Crystalline series (HHC) or a close analog, although subordinate contributions (probably $<20 \%$ ) from the Lesser Himalaya (LH) and High Himalayan Sedimentary Series (HHSS) are possible.

A model in which the the HHC are exposed to erosion since the early Miocene on the south flank of the orogen by thrusting along the MCT, while the HHSS is simultaneously removed by northward-directed normal faulting satisfies the contraints above. The results of this study require that the Himalaya have been a significant topographic feature since at least the early Miocene. Independent evidence supports this contention. Variations in the sedimentation style in the Bengal Fan since that time appear to represent a combination of factors, including tectonic activity and the coupled effects of climate and sea level changes. 
The Bengal Fan is the world's largest submarine fan, extending some $3000 \mathrm{~km}$ south into the Indian Ocean from Bangla Desh. The Bengal Fan has developed largely in response to the collision of India with Asia and the uplift of the Himalaya in Tertiary time (Gansser, 1966; Curray and Moore, 1971). Curray and Munasinghe (1989) have divided the Bengal Fan into precollisional and postcollisional sediments, based on the presence of an Early Eocene unconformity. The Fan reaches a maximum thickness of over $22 \mathrm{~km}$ and the mass of the postcollision sediments is estimated at 2.9x1016 tons (Curray, 1991). The Bengal Fan is fed by the Ganges-Brahmaputra river system, which currently drains both the north and south slopes of the Himalaya. The great relief, monsoon climate and extensive glaciation of the Himalayan region combine to produce some of the world's highest erosion rates. The Ganges-Brahmaputra system provides $24 \%$ of the river particulate flux to the world oceans, while providing less than $3 \%$ of the water flux (Milliman and Meade, 1983). Chemical erosion is also important in this watershed - the Ganges-Brahmaputra system carries three times the dissolved load of major cations than would be predicted from global average trends (Sarin et al., 1989).

The Bengal Fan provides an unparalleled record of Himalayan erosion, which in turn is related to the collision history of India and Asia, and the uplift history of the Himalaya. Erosional processes are also related to climate, thus the Bengal Fan may record information about climate change in the regions that supplied it with sediment. The Bengal Fan has been sampled by underwater drilling, permitting a reconstruction of the erosion history of the Himalaya in Neogene time. We wish to address several questions: What were the sources of sediment to the Bengal Fan, and have these sources varied in time? How can we use the sedimentological record to constrain the erosion history of the source regions? What is the relative importance of physical versus chemical erosion in the denudation of the Himalaya? What role does climate change play in the sedimentation history of the Bengal Fan, and by inference, erosion in the Himalaya?

In this paper, we present sedimentologic and $\mathrm{Nd}, \mathrm{Sr}, \mathrm{O}$ and $\mathrm{H}$ isotopic data on samples recovered from the Bengal Fan by the Ocean Drilling Program during Leg 116. These samples yield a record of sedimentation in the Bengal Fan beginning in Early Miocene time. These data, along with sedimentological data from DSDP Leg 22 and new and compiled data on from some potential source regions are used to address the questions listed above. The sedimentological record of the Bengal Fan is an integrated record, sampling the Himalayas across the wide area of the Ganges-Brahmaputra watershed (1.48 million km2, Milliman and Meade, 1983). Thus the Bengal Fan record can yield important constraints on processes in the Himalayan source region unavailable from terrestrial studies. The stratigraphic resolution of the sedimentary record also permits a detailed comparison in time of sedimentary events and possible forcing factors, such as tectonic events or climate change.

Geology of Leg 116 Sites

Ocean Drilling Project (ODP) sites 717, 718 and 719, drilled during Leg 116 are located in the distal portion of the Bengal Fan (Fig. 1). The holes are approximately $8 \mathrm{~km}$ apart. Hole 717C 
penetrated 828 mbsf (meters below sea floor) bottoming in late Miocene sediments, while Hole 718C penetrated 935 mbsf, bottoming in early Miocene sediments. Hole 719B penetrated 466 mbsf, bottoming in late Miocene sediments. The principal lithologies encountered in all holes were silt and mud turbidites, with lesser but variable amounts of biogenic mud turbidites (Shipboard Scientific Party, 1989). Correlations between the holes are based primarily on lithostratigraphy and nannofossil biostratigraphy (Stow et al., 1990; Gartner, 1990). A number of potential problems exist with the assignment of biostratigraphic ages to these sediments. Most of the sequence appears to have been deposited near or below the CCD, thus the state of preservation of calcareous fossil material is often poor. Second, it is probable that most of the fossils in the turbidites of the Bengal Fan have been redeposited, and thus fossil-bearing horizons would actually be younger than indicated. However, the succession of highest and lowest occurrences of fauna is both self-consistent and closely comparable with that observed in contemporaneous pelagic sediments, suggesting that redeposition has not seriously disturbed the biostratigraphic record (Gartner, 1990).

Stow et al. (1990) have presented a detailed summary of the sedimentology of Sites 717, 718 and 719. Lower to upper Miocene sediments are characterized by silt and mud turbidites. The latest Miocene, Pliocene, and early Pleistocene are characterized by mud turbidites, with interbedded silt turbidites, biogenic turbidites and pelagic clays. In the mid-upper Pleistocene section, sandy and silt- to mud turbidites dominate, except for the last few meters of Holocene pelagic oozes. Variations in sedimentation rates derived from biostratigraphy are consistent with the lithologic variations. Overall, sedimentation rates were high $(70-200 \mathrm{~m} / \mathrm{Ma})$ during the early and middle Miocene, low (20-70 m/Ma) during the late Miocene-early Pleistocene, and very high $(>200 \mathrm{~m} / \mathrm{Ma}$ ) from the early Pleistocene to the Holocene (Gartner, 1990). A wide variety of detrital minerals have been identified in the Bengal Fan silts, the most common of which are quartz, feldspars, carbonates, micas, amphiboles and epidotes (Yokoyama et al., 1990). Two clay facies have been identified in the $<2 \mu \mathrm{m}$ Leg 116 sediments: an illite-chlorite rich assemblage (IC) and a smectite-kaolinite rich assemblage (SK) (Bouquillon et al. 1990; Brass and Raman, 1990). The IC assemblage is dominant from the lower Miocene to upper Miocene, the SK assemblage from the upper Miocene to the lower Pleistocene, and the IC assemblage returns above the lower Pleistocene.

Figure 2 presents a summary of the above data for Hole 717C. Also shown are maximum quartz grain size (MQGS) data obtained from smear slide analysis (Shipboard Scientific Party, 1989). Changes in lithology, clay mineralogy, MQGS and sedimentation rate are correlated. Prior to ca. 11 Ma the sedimentation record in Hole $718 \mathrm{C}$ is marked by silt turbidites and coarse MQGS, although the overall sedimentation rate near the bottom of Hole 718C is apparently lower than during other intervals of similar lithology. Cochran (1990) argued that an increase of pelagic facies near the bottom of $718 \mathrm{C}$ indicates an early stage of submarine fan development. Thus the lower sedimentation rate below about 650 mbsf may simply reflect less sediment supply to this distal portion of the Fan in its early stages of development. The increase in sedimentation rate after $11 \mathrm{Ma}$ correlates with a sea level drop at about 10.5 Ma, and with the establishment of the "modern" Ganges delta (Haq et al., 1987; Cochran 1990; Lindsay et al., 1991). The Pliocene section is better developed at Sites 717 and 719, perhaps due to non-deposition or erosion at Site 718. All holes show a drop in sedimentation rate at ca. $6.8 \mathrm{Ma}$ (Fig. 3). This change is evident in the lithology and the MQGS data. It also corresponds to a marked change in clay mineralogy at all three sites, from the IC assemblage to the SK assemblage (Fig. 2). Coarser clastic deposition recurred for a brief period prior to $3.5 \mathrm{Ma}$. The sedimentation rate increased markedly at all three Sites at $0.8 \mathrm{Ma}$, 
accompanied by a return to coarse clastic sedimentation and the IC clay assemblage.

Lithostratigraphic and biostratigraphic correlations between the three Sites are good at this scale

of study, providing further confidence in the biostratigraphic ages assignments (e.g. Shipboard

Scientific Party, 1989).

DSDP Site 218, Leg 22, is located approximately $1100 \mathrm{~km}$ north of the Leg 116 Sites

(Fig. 1). Drilling encountered similar lithologies, bottoming at $773 \mathrm{mbsf}$ in Middle Miocene turbidite sediments (Figs. 1, 4) (von der Borsch, Sclater et al., 1974). We correlate Site 218 with Sites 717, 718, and 719 based on lithostratigraphy and biostratigraphy (von der Borsch, Sclater et al., 1974; Gartner et al., 1974). At Site 218, changes in lithology, grain size, and clay mineralogy similar to those at the Leg 116 Sites support this correlation (Pimm, 1974; Bouquillon et al., 1989).

The occurrence of correlative lithologies, grain size distributions, sedimentation rate and clay mineral assemblages at three different Leg 116 Sites, located near $1^{\circ} \mathrm{S}$, and at Site 218 , located at $8^{\circ} \mathrm{N}$, demonstrates that the important variations in the sedimentation history of the DSDP and ODP sites reflect regional phenomenon. Pimm (1974) also noted that clastic sediment pulses were correlative over long distances both within the Bengal Fan and into the Nicobar Fan. Such a wide geographic dispersion precludes channel switching or other changes in the location of depocenters as an explanation for the variations in sedimentation rate and lithology. It is also improbable that simply changing the channel network in the Fan, without a change in sediment source, could result in significant changes in the mineralogic composition of the $<2 \mathrm{~mm}$ clay fraction. Finally, studies of other submarine fans suggest that levee construction takes place on a 105 year time scale, but the major variations in sediment composition observed at the Leg 116 sites and Site 218 are of 106 years duration, implying that simple construction of underwater structures is not the process responsible for the sedimentological variations (e.g. Damuth et al., 1988; Manley and Flood, 1988). The implications of the basin-wide nature of stratigraphic events in the Bengal Fan are that the sedimentological variations are caused by 1) changes in provenance, and/or 2) changes in transport phenomena in the Ganges watershed or near the head of the Bengal Fan complex.

Analytical Methods

Samples of sediment from ODP collections were selected to provide a range in age and sedimentary facies. Samples were first disaggregated in distilled water. The coarse fraction ( $>$ $63 \mu \mathrm{m}$ ) was separated by screening, and the remainder either analyzed as the $<63 \mu \mathrm{m}$ fraction or subject to further size separation. Mono-mineralic separates were prepared from the $>63 \mu \mathrm{m}$ fraction by hand picking. The preparation of $<2 \mu \mathrm{m}$ and $2-50 \mu \mathrm{m}$ fractions generally followed the methods described in Bartoli et al. (1991) and Feller et al. (1991). Briefly, the samples (including both those previously screened at $63 \mu \mathrm{m}$, or those previously untreated) were disaggregated by agitation with Amberlite cation exchange resin ( $\mathrm{Na}$ form) for 16 hours. This treatment disperses the fine-grained particles because of the high exchange capacity of the resin. The samples were screened to remove $>50 \mu \mathrm{m}$ particles. The remaining fraction was allowed to sediment for 24 hours, effectively separating the $<2 \mu \mathrm{m}$ fraction. The suspended $2 \mu \mathrm{m}$ clays were decanted, and $1 \mathrm{ml}$ of a clean $\mathrm{MgCl} 2$ solution (Prolabo Normapur®) was added to flocculate the clays. This sequence was repeated as necessary. The $2-50 \mu \mathrm{m}$ and $<2 \mu \mathrm{m}$ fractions were then separated from solution by centrifugation. The quality of the grain size separations was periodically checked using a microscope-mounted image processing system. In all cases the size separation technique was found to be highly effective. A portion of the $<2 \mu \mathrm{m}$ fraction was 
subject to standard X-ray techniques for clay mineral identification.

Clay fractions were decarbonated by leaching with $10 \%$ acetic acid in an ultrasonic bath. Samples for $\mathrm{Sr}$ and $\mathrm{Nd}$ isotopic analysis were roasted at $700^{\circ} \mathrm{C}$ in platinum crucibles to remove organic matter. Samples were weighed and spiked, and dissolved in a HF-HNO3-HClO4 mixture. Separation procedures for $\mathrm{Rb}, \mathrm{Sr}, \mathrm{Sm}$ and $\mathrm{Nd}$ are described in Alibert et al. (1983). $\mathrm{Sr}$ and $\mathrm{Nd}$ isotopic compositions were measured on a Finnigan-MAT 262 mass spectrometer equipped with an SEM and 6 faraday detectors. Blanks are estimated at ca. $0.5 \mathrm{ng}$ for $\mathrm{Nd}$ and 1 ng for $\mathrm{Sr}$ (blank $87 \mathrm{Sr} / 86 \mathrm{Sr} \approx 0.710$ ). These high blanks result from the complex sample preparation procedure. However, samples sizes were sufficiently large that blank corrections are not necessary.

Oxygen from silicates were extracted by fluorination following the technique of Clayton and Mayeda (1963). CO2 gas was analyzed on VG 602D mass spectrometer. All extractions were duplicated and average reproducibility on clay samples is $\pm 0.3 \%$.

\section{Results}

Mineralogic, isotopic and major element data are listed in Tables 1 and 2 for whole rock samples, mineral separates and granulometric fractions. Figures 5 and 6 show composite logs of the isotopic compositions of $\mathrm{Nd}, \mathrm{Sr}, \mathrm{O}$ and $\mathrm{H}$ as a function of depth/age at Sites 717 and 718 for the different mineral separates or size fractions analyzed. Isotopic analyses of coarse mineral separates and most XRD analyses are from Bouquillon et al. (1990). Isotopic analyses of Sr for the $<2 \mu \mathrm{m}$ fraction samples given in Bouquillon et al. (1990) were not retained here because these samples were not leached with acetic acid prior to analysis, and are thus not directly comparable.

\section{Neodymium and Strontium}

The isotopic compositions of $\mathrm{Nd}$ and $\mathrm{Sr}$ are remarkably uniform over the whole stratigraphic column. $\mathrm{eNd}(0)$ values are between -17 and -14 ; the entire range is from -13.8 to -19.3 (mean=-16.0, std. dev.=1.2). The two lowest values are from SK samples, however no clear difference is evident overall between SK and IC samples (Figure 7). 87 Sr/86Sr ratios for all samples vary between 0.720 and 0.762 (mean=0.741, std. dev.=0.009). For both the whole rock and granulometric fractions $87 \mathrm{Sr} / 86 \mathrm{Sr}$ is independent of $\mathrm{Sr}$ concentration, which supports the efficiency of the leaching technique in removing carbonates containing non-radiogenic seawater-derived Sr. SK and IC samples have similar $87 \mathrm{Sr} / 86 \mathrm{Sr}$ ratios. Not only are $87 \mathrm{Sr} / 86 \mathrm{Sr}$ ratios relatively homogeneous with depth, but also across a variety of mineralogies, despite large variations in $\mathrm{Rb} / \mathrm{Sr}$ ratio.

Stable isotopes

$\mathrm{d} 180$ values of coarse quartz are remarkably constant with depth at $12.8 \%$ o \pm 0.5 . Mixtures of coarse biotite and chlorite vary from 7.2 to $9.8 \%$ and are depleted in 180 with regard to quartz. The d difference between quartz and biotite is 3.6 to $5.6 \%$, which corresponds to an isotopic equilibrium temperature between 500 and $650^{\circ} \mathrm{C}$ (e.g. Botinga \& Javoy, 1975). Despite the fact that these analyses represent average values of single grains of different origin this average "fractionation" between quartz and biotite is likely to reflect high temperature fractionation in the source rock.

The $<2 \mu \mathrm{m}$ fraction samples display two groups of $\mathrm{d} 18 \mathrm{O}$ values. IC samples are between 
11.5 to $15 \%$, whereas SK samples are more variable and significantly enriched in $18 \mathrm{O}$ at 18.2 to $22.6 \%$. The values for IC are extremely low for clay minerals, especially in marine sediment. "Normal" values of marine clays are in the range of 16 to $25 \%$, with most between 20 and $25 \%$ (Savin \& Epstein 1970, Yeh \& Savin 1977, Perry et al., 1976; Laurence et al. 1979, Taieb 1990). High values are due to large isotopic fractionation between clay and water at low temperature (e.g. Yeh \& Savin, 1977). The IC assemblage clays have not been enriched in $18 \mathrm{O}$ by low temperature exchange. Like the coarse micas, the IC clays reflect the high temperature of their source rock, whereas smectite and kaolinite were formed at low temperature.

\section{Discussion}

Sources of sediment in the Bengal Fan

The $\mathrm{Nd}, \mathrm{Sr}, \mathrm{O}$ and $\mathrm{H}$ isotopic data impose several constraints on the sources of the sediments in the Bengal fan:

- the remarkably constant $\mathrm{Nd}, \mathrm{Sr}$ and $\mathrm{O}$ isotopic values with time are a strong indication that the material has been derived from the same major source or melange of sources since 17 Ma. The isotopic data are consistent with the overall monotony of the mineralogy. The stratigraphic levels rich in SK clays have higher $\mathrm{d} 18 \mathrm{O}$ values than elsewhere in the column, but have the same $\mathrm{Nd}$ and $\mathrm{Sr}$ values as the coarse fraction and samples of the IC clay assemblage.

- the source(s) of this material is old, with a long crustal residence time. Nd model ages are ca. $2.0 \mathrm{Ga}$ in the sediments at all levels, and $87 \mathrm{Sr} / 86 \mathrm{Sr}$ cluster about 0.74 . The $\mathrm{d} 18 \mathrm{O}$ values of quartz and micas are also typical of silicic crystalline crustal sources, such as paragneisses and S-type granites.

- the present-day isotopic composition of $\mathrm{Sr}$ is quite homogeneous, despite high but variable $\mathrm{Rb} / \mathrm{Sr}$ ratios. This requires a recent metamorphic/magmatic event in the source to isotopically homogenize the $\mathrm{Rb}$-Sr system shortly before erosion and deposition of the sediments.

- in the IC levels $\mathrm{d} 18 \mathrm{O}$ values are very low for the $<2 \mu \mathrm{m}$ clay fraction compared to normal deep sea clays $(\approx 13 \%$ ). The $\mathrm{d} 18 \mathrm{O}$ data reinforce the observation that low temperature alteration minerals are present only in minor abundance in IC levels, which implies that erosion was dominated by physical rather than chemical processes.

- the SK levels are enriched in D and 180 relative to IC levels, but have the same $\mathrm{Nd}$ and $\mathrm{Sr}$ signature. This implies that smectite and kaolinite are derived from the same material as the illite and chlorite. The SK clays appear to be altered equivalents of the IC material, which preserves the radiogenic isotopic compositions but results in higher $\mathrm{d} 18 \mathrm{O}$ and $\mathrm{dD}$ values.

We now examine potential sources for the Bengal Fan sediments around the Bengal Basin. Early studies of the Bengal Fan concluded that the Himalaya were the primary source for detrital material (Curray and Moore, 1971; Shipboard Scientific Party, 1974; Ingersoll and Suczek, 1979). Several authors have used mineralogical criteria to identify the presence of several additional components in the Bengal Fan (Bouquillon et al.,1989; Brass and Raman, 1990; Stow et al., 1990; Yokoyama et al., 1990). The most important of these include the Precambrian terranes of south India and the Deccan Traps. Both of these terranes are a potential source of the smectite and kaolinite clays which are common in some Bengal Fan strata. Stow et al. (1990) proposed that dark-grey and organic rich turbidites, which correspond to some SK levels drilled on Leg 116, are derived either from the Deccan Traps or the granulite terrains of India and Sri Lanka. This is not supported by the isotopic composition of $\mathrm{Sr}$ and $\mathrm{Nd}$ in such 
dark-grey turbidites (e.g. 717C-24X, 66-67 cm and 717C-35X, 28-29 cm) which are indistinguishable from other facies. A component derived from these granulites should be easily resolved isotopically, with $\mathrm{eNd}(0)<-30$ and $87 \mathrm{Sr} / 86 \mathrm{Sr} \approx 0.716$ (e.g. Peucat et al., 1989). The Deccan Traps are equally distinctive with $\mathrm{eNd}(0)>0$ and $87 \mathrm{Sr} / 86 \mathrm{Sr}<0.708$, except for volumetrically minor early flows (e.g. Mahoney et al., 1982; Lightfoot et al., 1990).

Three arguments suggest that non-Himalayan sources are minor. First, the similarity of $\mathrm{Nd}$ and $\mathrm{Sr}$ isotope ratios between IC and SK levels imply that the smectite and kaolinite have the same source as the illite, chlorite and coarser material. Furthermore, soils from the Ganges delta (Table 2) and the suspended matter of the Ganges and Brahmaputra (Goldstein, 1988; Goldstein et al., 1984) have $\mathrm{Nd}$ and $\mathrm{Sr}$ isotopic compositions identical with those of the Bengal sediments (Fig. 8). Second, the deposition rate at the Leg 116 sites is very high even during periods when the SK assemblage is dominant, and the relief and the rivers from Sri Lanka and eastern India are not likely to supply a significant amount of sediments compared to the Ganges-Brahmaputra system. Finally, the same type of smectite and kaolinite parageneses associated with variable proportions of illite and chlorite are observed (1) in the Tertiary sediments of the Siwaliks (e.g. Mukherjee, 1964), (2) in the Ganges delta soils (Rahman, 1987), (3) in the Ganges river suspended matter (Sarin et al., 1989) and (4) in the proximal Bengal Fan (Bouquillon et al. 1989). Thus it is not necessary to call on the presence of components derived from the southern Indian shield or Sri Lanka to explain the clay mineral abundances found in the Bengal Fan sediments, as proposed by previous workers (Brass and Raman, 1990; Stow et al., 1990). While material derived from south India, Sri Lanka and the Deccan Traps is certainly present in the Bengal Fan, the isotopic data demonstrate conclusively that such components are of minor volumetric importance.

We can compare the isotopic compositions of the Bengal Fan sediments with potential Himalayan sources in some detail (Fig. 7). Despite the large area of the Ganges-Brahmaputra watershed, the gross structure of the Himalaya is relatively simple and regular throughout the range (e.g. Gansser, 1964; Le Fort, 1989). The three main Himalayan structural/stratigraphic units have very distinct isotopic features. The Lesser Himalaya (LH), dominated by old Himalayan metasediments ( $>1.8 \mathrm{Ga}$; Deniel, 1985), have very high $\mathrm{Sr}$ isotope ratios and eNd(0) around -25, reflecting their long crustal evolution (France-Lanord and Le Fort, 1988; Parrish et al., 1992; Table 2). The High Himalaya Crystalline metasedimentary series (HHC), located above the Main Central Thrust (MCT), have been intensely investigated to examine the genetic relations between the paragneisses and the overlying leucogranites (e.g. Scaillet et al., 1990). Averages of eNd(0) and $87 \mathrm{Sr} / 86 \mathrm{Sr}$ are -15 and 0.740 respectively (Fig. 8). The Himalayan leucogranites, which are derived from the HHC, have similar ranges. The High Himalaya Sedimentary Series (HHSS) are Cambrian to Eocene in age, and include limestones, sandstone, shales and some volcanic material. Nd and Sr isotopic data for HHSS sediments are given in Table 2. These data do not provide a comprehensive view of the HHSS but indicate that this unit is isotopically variable, as would be expected of a sedimentary sequence with a wide age range in an evolving tectonic setting. They have higher eNd(0) and lower $87 \mathrm{Sr} / 86 \mathrm{Sr}$ than the $\mathrm{HHC}$ (Fig. 7), indicative of their younger source ages and, for some, the presence of volcaniclastic components. On histograms of isotopic compositions of $\mathrm{Nd}, \mathrm{Sr}, \mathrm{O}$ and $\mathrm{H}$, the $\mathrm{HHC}$ paragneisses appear extraordinarily concordant with the Bengal sediments (Fig. 7). In contrast, the LH and HHSS lie outside the narrow range of values shown by the Bengal Fan. Thus the major source for the detrital material has been an equivalent to the modern HHC, and the LH and the HHSS must be subordinate to the HHC. This is consistent with the present structure of the Himalaya. The 
$\mathrm{HHC}$ is exposed on the southern flank of the high ranges of the Himalaya, which is the region of highest relief and precipitation, hence of most rapid erosion. Conversely, the HHSS is exposed on the north flank of the range, and is undergoing less erosion. The LH contributes relatively little to the Bengal sediments, because it is at a lower elevation, is not glaciated, and is under extensive plant cover.

A more quantitative estimate of the relative importance of the Lesser Himalaya, the High Himalaya Crystalline series, and the High Himalayan Sedimentary Series in supplying Bengal fan sediment may be obtained from isotopic mass balance. Taking average values of each of the three groups, Nd-Sr mass balance suggests that the contribution of LH and HHSS sediments to the Bengal Fan could have varied between 0 and $40 \%$, but was most often closer to the lower of these two estimates. In principle, the $\mathrm{Nd}$ and $\mathrm{Sr}$ signature of the Bengal Fan could be produced by a simple mixture of LH and HHSS. Two points mitigate against this interpretation. First, the ranges of $\mathrm{Nd}$ and $\mathrm{Sr}$ values in the Bengal sediments are very narrow at all times. The LH and HHSS lie in structurally and topographically distinct parts of the Himalayan Range. It is rather improbable that a mixture of LH and HHSS would always fall in the same narrow range, despite important changes in sedimentation rate, mineralogy, and tectonic and climactic history. Second, the sediments have highly variable $\mathrm{Rb} / \mathrm{Sr}$ ratios. This variability would give rise to a wide range in $87 \mathrm{Sr} / 86 \mathrm{Sr}$ values in the sediments over the time scale of the age of the HHSS and the LH. In fact, $87 \mathrm{Sr} / 86 \mathrm{Sr}$ varies only slightly in the Bengal Fan, implying that the sediment source was isotopically homogeneous on the order of 10-100 Ma before present. This constraint is not satisfied by the HHSS or the LH because the Himalayan metamorphism sensu lato is weak or only locally developed in these units (e.g. Le Fort, 1986). However, the total amount of erosion of the HHSS may be underestimated by the record of clastic sediments of the Bengal Fan. At least $50 \%$ of the HHSS is composed of platform carbonates that are mostly dissolved during the erosional process. The abundance of detrital grains of dolomite before $\approx 10 \mathrm{Ma}$ in Hole $718 \mathrm{C}$ (Yokoyama et al., 1990) reflects a higher proportion of carbonate rocks in the source during the early stage of Fan development which could be a by-product of early Miocene erosion of the HHSS.

\section{Implications for Himalayan tectonics since $17 \mathrm{Ma}$}

The first order conclusion from the isotopic data is that an equivalent of the High Himalayan Crystalline series has been the dominant source of sediment supply to the Bengal fan since before $17 \mathrm{Ma}$. This situation has apparently not varied significantly since that time, despite changes in sedimentation rate in the Fan, alteration history of the sediments, and tectonic and/or climactic changes that may have affected the erosional history of the Himalayan source regions. In a few samples, there is a hint of low eNd(0) material, presumably from either an Indian or LH source. However, this component is always minor, and in most cases not resolvable. The presence of large volumes of sediment derived from the HHC since at least as early as $17 \mathrm{Ma}$ has significant implications for the tectonic history of the Himalaya. Obviously, the sedimentary record requires that the $\mathrm{HHC}$ have been exposed at the surface since that time. Furthermore, as argued above, the mineral assemblage (e.g. Yokoyama et al., 1990), $87 \mathrm{Sr} / 86 \mathrm{Sr}$ and stable isotopic values in Bengal sediments are indicative of a metamorphic source which experienced isotopic homogenization of Sr shortly before erosion and deposition. The majority of single grain 40Ar/39Ar dates of feldspar and muscovite of Leg 116 sediments are in the range of 10 to $50 \mathrm{Ma}$ (Copeland and Harrison, 1990). This evidence is also consistent with a HHC source, and implies that the high temperature metamorphic rocks from the $\mathrm{HHC}$ were being eroded at $17 \mathrm{Ma}$. The 
large volume of sediment supply to the Bengal Fan requires that the Himalaya were a significant topographic feature throughout this time. Furthermore, the observation that the sources of Bengal sediment have not varied implies that the main lithologies present in the high range were closely analogous to the present HHC. Therefore the general structure of the high range has remained grossly similar since the early Miocene, with the HHC exposed to rapid erosion, while the HHSS and LH have remained in less susceptible positions. A plausible hypothesis is that the $\mathrm{HHC}$ have been maintained continuously at the top of the chain by southward-directed thrusting, and that the overlying HHSS have been simultaneously removed by north-directed normal faulting (Fig. 9). In this way the HHSS has been protected from erosion, while the HHC has formed the region of high elevations and relief.

The source of the SK assemblage

The Nd and Sr data show that the IC and SK clay assemblages have the same source, but their O and $\mathrm{H}$ isotope compositions are different (Figs. 5, 6, 7). The IC and SK assemblages therefore represent differences in alteration history of the same material. The $\mathrm{d} 18 \mathrm{O}$ values of $+20 \%$ and $\mathrm{dD}$ values of $-65 \%$ in the SK samples are consistent with alteration by meteoric water in the Indo-Gangetic Plain at ca. $20^{\circ} \mathrm{C}$. It is essentially variation in the smectite/illite ratio that is responsible for the mineralogic difference between the two clay assemblages. Kaolinite is found in both IC and SK samples (Table 1), and in lakes and river sediments of the High Himalayan chain (CRPG unpublished data; Sarin et al., 1989). Conversely, smectite only appears downstream of the Siwaliks in the Indo-Gangetic plain. The ratio of smectite to illite in the Ganges river sediments increases downstream, from zero in the highlands to 6-8 in the Indo-Gangetic Plain (Sarin et al., 1989). Estimates of d180 and dD in Bengal smectites correspond with those of clays generated during continental alteration, but are too low to be generated by reaction with cold seawater in the deep ocean (Bouquillon et al.,1990). While carbonate precipitation has occured in the section, there is no evidence that diagenetic processes have significantly affected the clastic material in Bengal Fan sediments (e.g. (Bouquillon et al., 1989). We conclude that the alteration which has produced the SK assemblage occured during transport in the Ganges-Brahmaputra river system. The intervals rich in SK clays represent periods when the eroded material was altered at low temperature prior to its sedimentation. This process could take place in several ways. Clays could be altered during river transport, they could be deposited in the foreland basin and re-eroded under a warm climate regime, or they could be altered during residence in the Indo-Gangetic plain.

Variation in sedimentation history of the Bengal Fan

Between 6.5 and 0.8 Ma, the change in sediment facies, high abundance of smectite, fine grain size, and lower accumulation rates (Fig. 3) indicate a major change in the supply of sediment to the Bengal Fan. Such an event may be related to tectonic evolution of the Himalaya, climatic variations, sea level changes or some combination of these factors.

Major eustatic sea level changes have occured several times since the Miocene (Haq et al., 1987), and Cochran (1990) proposed that this has been the main control on sedimentation in the distal Fan. During periods of low sea level stand, the delta should be exposed to erosion, and sediments will be redeposited in the deep sea. During periods of high sea level, sediments should be impounded in the delta, and coarse clastic deposition cut off from the distal Fan. A major sea level lowstand at 10.5 Ma has resulted in major erosion of the Ganges-Brahmaputra 
delta (Lindsay et al., 1991). The drop in sea level observed at 10.5 Ma and attributed to Antarctic ice sheet growth (Shackelton and Kenneth, 1975; Miller et al., 1987) corresponds to an increase in the accumulation rate in the Hole 718C. However, despite an important rise in sea level after this time, which corresponds to the beginning of growth of the "modern" delta (Lindsay et al., 1991), deposition rates and sediment facies in the distal Bengal Fan remain essentially unchanged (Fig. 4). The sedimentation rate at the Leg 116 sites does begin to drop around 6.8 Ma with the appearance of the SK assemblage, which corresponds to a new rise in sea level (e.g. Cochran, 1990). However, other equally important variations in sea level are not followed by changes in sedimentation, especially between 3 and $1 \mathrm{Ma}$. The Bengal Fan does show a striking change in sedimentation at about $0.8 \mathrm{Ma}$. This event apparently correlates with the onset of major glacial cycles in the mid-Pleistocene. It seems unlikely that the prominent stratigraphic break at 0.8 Ma merely reflects a (possibly) somewhat more pronounced drop in sea level. Rather, the data suggest that Himalayan erosion rates increased at $0.8 \mathrm{Ma}$, perhaps due to increased alpine glaciation, perhaps due to renewed tectonic activity (c.f. Burbank and Johnson, 1983). Furthermore, large Quaternary glacial-interglacial sea level changes are not evident in the distal Fan. Bouquillon et al. (1989) find only minor changes in the smectite-illite ratio of clays from the delta and proximal Fan during Pleistocene glacial-interglacial cycles. If the relation between sea level and erosion in the Ganges-Brahmaputra delta is relatively clear, the relation between sea level and sedimentation in the distal Fan is evidently not so simple. Additional evidence against a simple relation between sea level and Fan sedimentation comes from the early and mid-Miocene. Prior to $11 \mathrm{Ma}$ sea level was, on average, higher than during the highstand between 5 and $3 \mathrm{Ma}$ (Haq et al., 1987) but sedimentation in the Bengal Fan was dominated by coarse and illite-rich sediments. Nor is a major change in the marine $\mathrm{d} 18 \mathrm{O}$ record at $14 \mathrm{Ma}$, the largest in mid-Tertiary time (Miller et al., 1987), reflected in the sedimentary record. This implies that other processes are important for controlling sedimentation in the distal Fan, particularly changes in the sediment supply from the river system. It is also important to remember that Neogene sea level changes have been driven by ice volume changes in many instances, therefore they correspond to episodes of climate change (e.g. Miller et al., 1987; Crowley and North, 1991). Climate change in the Himalayan source region of the Bengal Fan sediments can easily result in changes in erosion rate and thus sediment supply.

Studies of both the terrestrial record in Pakistan and the marine record in the Arabian Sea suggest that the monsoonal weather pattern intensified ca. 7 Ma (Quade et al., 1989; Kroon et al., 1991). This climactic change appears to be directly reflected in the sedimentation record of the Bengal Fan (Figs. 2, 3). The sedimentation rate decreases, while the clay mineralogy shifts to the SK assemblage. However, the relation between the monsoon climate and sedimentation in the Bengal Fan is complex. While the appearance of SK clays may simply be related to a warmer and more humid climate in the Indo-Gangetic Plain, monsoon conditions would be expected to increase erosion rates in the High Himalaya, and thus sedimentation rates in the deep sea. This apparent paradox remains to be resolved.

Ruddiman and Raymo (1988) and Ruddiman and Kutzbach (1989) have proposed that late Neogene uplift of the Himalaya and Tibetan plateau has driven regional and global climate change, including causing the onset of the monsoon. The Bengal Fan records no evidence of renewed uplift and increased erosion coincident with the intensification of the monsoon climate at 7-8 Ma. In fact, the Leg 116 results suggest the opposite - a decrease in sedimentation rate possibly related to a decrease in erosion in the Himalaya. Rather, our results require the presence of the Himalaya as a significant topographic feature since at least $17 \mathrm{Ma}$. This implies 
that the late Miocene establishment or enhancement of monsoonal circulation in the Indian region is related to factors other than uplift in the Himalaya.

Tectonic changes are likely to cause important variation in the supply of detrital sediment to the Indo-Gangetic plain. For example, a decrease in the relief and general elevation of the range would directly result in decreased erosion. Episodic variations of the exhumation rate could well be related to motion on the MCT between 20 to $10 \mathrm{Ma}$, and on the MBT since at least $5 \mathrm{Ma}$ (e.g. Le Fort, 1989). Direct evidence in favour of this hypothesis is, however, lacking. Various studies have suggested pulses of uplift based on cooling ages or faunal studies (e.g. Gansser, 1983) However, these data have proven very difficult to interpret in a unique way (Molnar and England, 1990; England and Molnar; 1990). A simple link between tectonics and sedimentation in the Bengal Fan is therefore not easy to demonstrate because to date, no reliable record of the past elevation history of the Himalaya is available. The Bengal fan itself is probably the best indication that the Himalaya was a highly elevated range since the early Miocene. Independent evidence to support high elevations in the mid-early Miocene comes from two sources. France-Lanord et al. (1988) have shown that rare chloritization of the Manaslu leucogranite was effected by meteoric water (dD values of chlorite are ca. -190\%o). This episode of chloritization has been dated at 14.7 $\pm 0.2 \mathrm{Ma}$ (39Ar/40Ar, Copeland et al., 1990). The $\mathrm{dD}$ value of the chloritizing water is estimated at $<-140 \%$, markedly lower than modern meteoric water on the southern flank of the High Himalaya (dD - 80\%o, France-Lanord et al., 1988), and very similar to meteoric water in Tibet (Yu et al. 1984; Grimaud et al., 1985). Such extremely low values imply that very strong altitude and temperature effects on the isotopic composition of precipitation were already in place at the tropical latitude of the Himalaya in the mid-Miocene. The second independent indication comes from evidence for large scale normal faulting coaxial with the axis of compression at around $20 \mathrm{Ma}$. Pêcher (1991) observed stretching lineations in the upper Manaslu granite which record movement on an overlying normal fault while the granite was still hot, ca. $21 \mathrm{Ma}$. Hodges et al. (1992) find evidence for significant extension along the Qomolangma detachment at the same time. Such coeval and parallel extension and compression suggests gravitational collapse of an already highly elevated region due to limitations in crustal strength (Molnar and Lyon-Caen, 1988) We believe that the Himalayan Range had already achieved an elevation of the same order as the present day by 17 Ma.

\section{Conclusion}

Turbidite sedimentation in the distal Bengal Fan began in the early Miocene, before $17 \mathrm{Ma}$. Sedimentological data from ODP Leg 116 and DSDP Leg 22 define three main intervals of depositional history. From 17 to $6.8 \mathrm{Ma}$, deposition was characterized by coarse clastic debris, high sedimentation rates, and clay mineralogy dominated by an illite-chlorite assemblage. Between 6.8 and $0.8 \mathrm{Ma}$, deposition rates decreased, along with grain size, and clays were composed primarily of a smectite-kaolinite assemblage. After $0.8 \mathrm{Ma}$ there was an abrupt return to coarse clastic sedimentation, very high accumulation rates, and the illite-chlorite clay assemblage.

$\mathrm{Nd}, \mathrm{Sr}$ and $\mathrm{O}$ isotopic measurements of Bengal Fan sediments from all stratigraphic levels are very uniform, implying a single dominant source for the entire period since $17 \mathrm{Ma}$. The $\mathrm{Rb}$-Sr isotopic system in this source was apparently homogenized not long before erosion and deposition of the sediment. Oxygen isotopic systematics on coarse quartz and micas also imply 
a high temperature metamorphic source, consistent with the observed mineralogy of the detrital sediments (e.g. Yokoyama et al., 1990). A comparison of possible sources for the Bengal Fan sediments shows that the High Himalayan Crystalline series closely satisfies the above requirements, and that alternative sources do not. Isotopic mass balance suggests that only $20 \%$ or less of the Bengal Fan sediment was derived from other Himalayan sources such as the Lesser Himalaya or High Himalayan Sedimentary Series, although occasionally this fraction may have been as large as $40 \%$. The isotope data show no resolvable contribution from the Indian subcontinent.

Bengal Fan sediments from IC periods are unaffected by low temperature alteration, implying that physical erosion has been dominant over chemical erosion. The smectite-kaolinite clay mineral assemblage apparently is produced from the same source material by low temperature meteoric alteration in the Indo-Gangetic Plain. The appearance of this assemblage in the Bengal fan appears to correlate with an intensification of the monsoon climate around 7 Ma. Paradoxically, the sedimentation rate and grain size in the Fan both decrease at the same time, implying that other factors are important as well.

The relative lack of LH and HHSS-derived material in the Bengal Fan has implications for the structure of the Himalayan Range since the early Miocene. Southward-directed thrusting on the MCT-MBT system has been accompanied by simultaneous removal of the HHSS by northward-directed normal faulting. The large quantity of Bengal Fan sediment which arrived in the Indian Ocean at $1^{\circ} \mathrm{S}$ at $17 \mathrm{Ma}$ requires that the Himalaya have been a significant topographic feature at least since that time. Independent evidence supports this hypothesis, and we believe that the Himalaya have been at or near their present elevation since early Miocene time.

Evidence for significant uplift in the Himalaya during late Miocene and Pliocene time is absent in the Bengal Fan sedimentary record.

This study was carried out under the auspices of the French program 'Dynamique et Bilans de la Terre - Fieuve et érosion'. We thank P. Copeland, P. Le Fort, A. Galy and A. Moore for helpful discussion and review. We are grateful to J.J. Tiercelin, G. Mascle and T. Heulin who provided samples for this study. G. Burtin is thanked for his efficient help in clay separation. R. Taieb, D. Dautel and F. Lothe are thanked for their analytical support. CRPG contribution $\mathrm{N}^{\circ} 951$. CNRS-INSU-DBT contribution $\mathrm{N}^{\circ} 490$.

\section{Bibliography}

Alibert, C., Michard, A., \& Albarède, F., 1983. The transition from alkali basalts to kimberlites: isotope and trace element evidence from melilites. Contribution to Mineralogy and Petrology, 82, 176-186.

Bartoli, F., Burtin, G. \& Herbillon, A.J. 1991. Disagregation and clay dispersion of oxisols: Na resin, a recommended methodology. Geoderma, 49, 301-317.

Blattner, P., Dietrich, V., \& Gansser, A. 1983. Contrasting 18-O enrichment and origins of High Himalayan and Transhimalayan intrusives. Earth and Planetary Science Letter 65, 276-86.

Bottinga, Y., \& Javoy, M. 1973. Oxygen isotope partitioning among the minerals in igneous and metamorphic rocks. Review of Geophysic and Space Physic, 13, 401-418.

Bouquillon, A., 1987. Influence continentales et marines dans les sédiments Cénozoiques de 
l'ocean Indien Nord Oriental. Unpublish. Unpublished Thèse doct. Université de Lille Flandres-Artois, France, 270p.

Bouquillon, A., Chamley, H., \& Fröhlich, F., 1989. Sédimentation argileuse au Cénozoïque supérieur dans l'océan Indien Nord-oriental. Oceanologica Acta, 12, 133-147.

Bouquillon A., France-Lanord C., Michard A. \& Tiercelin J.-J. 1990 Sedimentology and isotopic chemistry of the Bengal fan sediments: the denudation of the Himalaya. in Cochran, J.R., Stow, D.A.V. et al., Proceedings of the Ocean Drilling Program, Scientific Results, 116, 43-58.

Brass, G. W. \& Raman, C.V. 1990 Clay mineralogy of sediments from the Bengal fan. in Cochran, J.R., Stow, D.A.V. et al., Proceedings of the Ocean Drilling Program, Scientific Results, 116: College Station, TX (Ocean Drilling Program) 35-41.

Burbank, D.W. \& Johnson, G.D. 1983. The la Cenozoic chronologic and stratigraphic development of the Kashmir intermontane basin, Northwestern Himalaya. Paleogeographyk, Palaeoclimatology, Paleoecology, 43, 205-235.

Clayton, R.N. \& Mayeda, T.D. 1963. The use of bromine pentafluoride in the extraction of oxygen from oxides and silicates for isotopic analysis. Geochimica et Cosmochimica Acta , $27,43-52$.

Cochran, J. R. 1990. Himalayan uplift, sea level, and the record of Bengal fan sedimentation at the ODP Leg 116 Sites. in Cochran, J.R., Stow, D.A.V. et al., Proceedings of the Ocean Drilling Program, Scientific Results, 116: College Station, TX (Ocean Drilling Program) 397-414.

Copeland, P. \& Harrison, T.M. 1990. Episodic rapid uplift in the Himalaya revealed by 40Ar/39Ar analysis of detrital K-feldspar and muscovite, Bengal fan. Geology, 18, 354-357.

Copeland, P., Harrison, T.M. \& Le Fort, P. 1990. Age and cooling history of the Manaslu Granite: Implications for Himalayan tectonics. Journal of Volcanology and Geothermal Research. 44, 33-50.

Crowley, T. J. \& North, G. R. 1991. Oxford Monographs on Geology and Geophysics, Paleoclimatology. Oxford University Press, Oxford.

Curray, J.R. 1991. Postcollision sediments in the Bay of Bengal. Eos, 72-44, 250.

Curray, J.R., \& Moore, D.G. 1971. Growth of the Bengal Deep-Sea Fan and Denudation in the Himalayas. Geological Society of America Buletin., 82, 563-572.

Curray, J.R. \& Munasinghe, T. 1989. Timing of intraplate deformation, northeast Indian Ocean. Earth and planetary Science Letters 94, 71-77.

Damuth J.E. \& Flood R.D. 1983. Morphology, sedimentation processes, and growth pattern of the Amazon deep-sea fan. Geo-Marine Letters 3, 109-117.

Damuth J.E., Flood R.D., Kowsmann R.O., Belderson R.H \& Gorini M.A. 1988. Anatomy and growth pattern of Amazon deep-sea fan as revealed by long-range side-scan sonar (GLORIA) and high-resolution seismic studies. The American Association of Petroleum Geologist Bulletin, 75, 885-911.

Deniel, C. 1985. Apport des isotopes du $\mathrm{Sr}, \mathrm{du} \mathrm{Nd}$ et du $\mathrm{Pb}$ à la connaissance de l'âge et de l'origine des leucogranites himalayens. Exemple du Manaslu (Himalaya, Népal). Unpublished Thesis Université de Clermont-Ferrand, France.

Deniel, C. ,Vidal, P., \& Le Fort, P. 1986. Les leucogranites himalayens et leur région source probable : les gneiss de la "Dalle du Tibet". Compte Rendu de l'Académie des Sciences, Paris 303, II, $\mathrm{n}^{\circ}$ 1, 57-60

Deniel, C., Vidal, P., Fernandez, A., \& Le Fort, P. 1987. Isotopic study of the Manaslu granite (Himalaya, Nepal) : Inferences on the age and source of Himalayan leucogranites. 
Contribution to Mineralogy and Petrology 96, 78-92.

Dietrich, V., \& Gansser, A. 1981. The leucogranites of the Bhutan Himalaya (crustal anatexis versus mantle melting). Bulletin Suisse de Minéralogie et Pétrographie, 61 177-202.

England, P \& Molnar, P. 1990. Surface uplift, uplift of rocks, and exhumation of rocks. Geology, $18,1173-1177$.

Feller, C., Burtin, G., Gérard, B. \& Balesdent, J. 1991. Utilisation des résines sodiques et des ultrasons dans le fractionnement granulométrique de la matière organique des sols. Intérêt et limites. Sciences du Sol. 29, 77-93.

France-Lanord C., \& Le Fort, P. 1988. Crustal melting and granite genesis during the Himalayan collision orogenesis. Transactions of the Royal Society of Edinburgh Earth Sciences, 79, 183-195.

France-Lanord, C., Sheppard, S.M.F., \& Le Fort, P., 1988. Hydrogen and oxygen isotope variations in the High Himalaya peraluminous Manaslu leucogranite : evidence for heterogeneous sedimentary sources. Geochimica et Cosmochimica Acta , 52, 513-526.

Gansser, A. 1964. Geology of the Himalayas. Intersciences Publishers, L.U. de Sitter Ed., 289p.

Gansser, A. 1966. The Indian Ocean and the Himalayas A geological interpretation. Eclogae geologicae Helvetiae, 59, 831-848.

Gansser, A. 1983. The morphogenic phase of mountain building. In Hsü, K. J. (ed.) Mountain building processes, pp. 221-228. Academic Press, London.

Gartner, S. 1990. Neogene calcareous nannofossil biostratigraphy, Leg 116 (Central Indian Ocean). in Cochran, J.R., Stow, D.A.V. et al., Proceedings of the Ocean Drilling Program, Scientific Results, 116: College Station, TX (Ocean Drilling Program) 165-187.

Gartner, S., Johnson, D. A. \& McGrowran, B. 1974.. Paleontology synthesis of deep sea drilling results from Leg 22 in the Northeastern Indian Ocean. in von der Borch, C. C., Sclater, J.C., et al., Initial Reports DSDP, 22: Washington, U.S. Government Printing Office, 805-813.

Goldstein, S.L. 1988. Decoupled evolution of Nd and Sr isotopes in the continental crust and the mantle, Nature, 336, 733-738.

Goldstein, S.L., O'Nions, R.K., \& Hamilton, P.J. 1984. A Sm-Nd isotopic study of atmospheric dusts and particulates from major river systems. Earth and Planetary Science Letters , 70, 221-236.

Grimaud D., Huang S., Michard G. \& Zheng K. 1985. Chemical study of geothermal waters of Central Tibet (China). Geothermics, 14, 35-48.

Haq, B.U., Hardenbol, J. \& Vail, P.R. 1987. Chronology of fluctuating sea levels since the Triassic. Science 235, 1156-1167.

Hodges, K.V., Burchfield, B.C., Chen, Z., Houst, T., Lux, D., Parrish, R. R. \& Royden, L.H. 1992. Rapid Early Miocene tectonic unroofing of the metamorphic core of the Himalaya: Evidence from the Qomolangma (Everest) region, Tibet Unpublished abstract of the 7th Himalaya-Karakoram-Tbet workshop. Oxford University, 6-8 April 1992, pp. 39.

Ingersoll, R. V. \& Suczek, C. A. 1979. Petrology and provenance of Neogene sand from Nicobar and Bengal Fans, DSDP Sites 211 and 218. Journal of Sedimentary Petrology. 49, 1217-1228.

Kroon, D., Steens, T., \& Troelstra S.R. 1991. Onset of monsoonal related upwelling in the western Arabian Sea as revealed by planktonic foraminfers. In Prell W.L., Niitsuma N., et al., Proceedings of the Ocean Drilling Program, Scientific Results 117: College Station, TX (Ocean Drilling Program), 257-263.

Lawrence, J.R.,, Drever, J.I., Anderson, T. F. \& Brueckner, H. K. 1979. Importance of alteration of volcanic material in the sediments of Deep Sea Drilling Site 323: chemistry, 18O/16O and 
87Sr/86Sr.Geochim. Cosmochim. Acta, 36: 573-588.

Le Fort, P. 1986. Metamorphism and magmatism during the Himalayan collision. in: Coward, M. P. \& Ries, A. C. (eds.), Collision Tectonics, Geological Society Special Publication, 19, 159-172.

Le Fort, P. 1989. The Himalayan orogenic segment. In: Sengör A.M.C (ed).Tectonic evolution of the Tethyan regions. Proceedings of the NATO ASI meeting, Istanbul, october 1985. Reidel Publ. Co.

Lindsay, J.F., Holliday, D. W. \& Hulbert, A.G., 1991. Sequence Stratigraphy and the Evolution of the Ganges-Brahmaputra Delta Complex. The American Association of Petroleum Geologist Bulletin, 75, 1233-1254.

Lightfoot, P.C., Hawkesworth, C.J., Devey, C.W., Rogers, N.W. \& Van Calsteren, P.W.C., 1990. Source and differentiation of Deccan Traps Lavas: Implications of Geochemical and Mineral Chemical Variations. Journal of Petrology, 31, 1165-1200.

Mahoney, J.J., Macdougall, J.D., Lugmair, G.W., Murali, A.V., Sankar Das, M., \& Gopalan, K., 1982. Origin of the Deccan Trap flows at Mahabaleshwar inferred from the $\mathrm{Nd}$ and $\mathrm{Sr}$ isotopic and chemical evidence. Earth and Planetary Sciences Letters, 60, 47-60.

Manley P.L. \& Flood R.D. 1988. Cyclic sediment deposition within Amazon deep-sea fan. The American Association of Petroleum Geologist Bulletin, 75, 912-925.

Miller, K.G., Fairbanks R.G. \& Mountain, G.S. 1987. Tertiary oxygen isotope synthesis, sea level history, and continental margin erosion. Paleooceonagraphy 2, 1-19.

Milliman, J.D., \& Meade, R.H. 1983. World Delivery of River Sediment to the Oceans, Journal of Geology , 1: 1-21.

Molnar, P. \& England, P. 1990. Late Cenozoic uplift of mountain ranges and global climate change: chicken or egg? Nature, 346, 29-34.

Molnar, P. \& Lyon-Caen, H. 1988. Some simple physical aspects of the support, structure, and evolution of mountain belts. Geological Society of America Special Paper, 218, 179-207.

Mukherjee, B. 1964. Clay minerals in argillaceous sediments of the Himalayan zone. Clay Minerals Bulletin, 5,363-372.

Parrish, R. R., \& Hodges, K.V.1992. U-Pb geochronology of igneous and metamorphic rocks near the Main Central Thrust in the Langtang area, Central Nepal Himalaya. Unpublished abstract of the 7th Himalaya-Karakoram-Tbet workshop. Oxford University, 6-8 April 1992.

Pêcher, A. 1991. The contact between the Higher Crystallines and the Tibetan Sedimentary Series: Miocene large-scale dextral shearing. Tectonics, 10, 587-598.

Perry, E.A., Gieskes, J.M., \& Lawrence, J.R. 1976. Mg, Ca and O18/O16 exchange in the sediment pore water system, Hole 149, DSDP. Geochimica et Cosmochimica Acta, 40, 413-423.

Peucat, J.J., Vidal, P., Bernard-Griffiths, J., \& Condie, K.C. 1989. Sr, Nd and Pb isotopic systematics in the Archean low-to-high-grade transition zone of southern India: Syn-accretion granulites. Journal of Geology, 97, 537-550.

Pimm A.C. 1974. Mineralization and trace element variation in dee-sea pelagic sediments of the Wharton basin, Indian Ocean. in von der Borch, C. C., Sclater, J.C., et al., Initial Reports DSDP, 22: Washington, U.S. Government Printing Office, 469-476.

Quade, J., Cerling, T.E. \& Bowman, J.R. 1989. Develpoment of Asian monsoon revealed by marked ecological shift during the latest Miocene in northern Pakistan. Nature, 342, 163-166.

Rahman, M.A.H.M., 1987. Amélioration de la fixation d'azote dans la rhizosphere du riz cultivé sur différents sols du Bangladesh. Unpublished Thesis Université de Nancy 1. 
Rao, A.T., \& Raman, C.V., 1986. Geochemical studies of clays from red sediments of Visakhapatnam coast, east coast of India. Indian J. of marine sc., 15:20-23.

Ruddiman,W.F.\& Kutzbach, J.E. 1989. Forcing of the late Cenozoic northern hemisphere climate by plateau uplift in southeast Asia ansd the American southwest. Journal of Geophysical Research 94, 18409-18427.

Ruddiman,W.F.\& Raymo, M.E. 1988. Northern hemisphere climate regimes during the past 3 Ma: possible tectoinic connections. Philosophical Transactions of the Royal Society (London) B 318, 411-430.

Sarin, M.M., Krishnaswami, S., Dilli, K., omayajulu, B. 1. K., \& Moore, W. S. 1989. Malor ion chemistry of the Ganga-Brahmaputra river system: Weathering processes and fluxes to the Bay of Bengal. Geochimica et Cosmochimica Acta, 53, 997-1009.

Savin, S.M. \& Epstein, S., 1970. The oxygen and hydrogen isotope geochemistry of ocean sediments and shales. Geochimica et Cosmochimica Acta, 34, 43-63.

Scaillet B., France-Lanord C., \& Le Fort P., 1990. Badrinath-Gangotri plutons (Garhwal, India) Petrological and geochemical evidence for fractionation processes in a High Himalayan Leucogranite. Journal of Volcanology and Geothermal Research. 44, 163-188.

Shackelton, N. J., \& Kennett, J. P. 1975. Paleotemperature history of the Cenozoic and the initiation of Antarctic glaciation: oxygen and carbon isotope analyses in DSDP Sites 277, 279 and 281. In Kennett, J. P., Houtz, R. E., et al., Initial Reports DSDP, 29: Washington (U.S. Gov. Printing Office), 743-756.

Shipboard Scientific Party, 1974.. Sites 2182 in von der Borch, C. C., Sclater, J.C., et al., Initial Reports DSDP, 22: Washington, U.S. Government Printing Office, 325-367.

Shipboard Scientific Party, 1989.. Initial Reports Sites 717-718-719 Distal Bengal Fan, Proceedings of the Ocean Drilling Program, Initial Reports., 116: College Station, TX (Ocean Drilling Program).

Stow, D. A. V., Amano, K., Balson, P.S. Brass, G.W., Corrigan, J., Raman, C.V., Tiercelin, J.-J., Townsend, M., \& Wijayananda, N.P., 1990. Sediment facies and processes on the distal Bengal Fan, Leg 116. in Cochran, J.R., Stow, D.A.V. et al., Proceedings of the Ocean Drilling Program, Scientific Results, 116: College Station, TX (Ocean Drilling Program) 377-396.

Taieb, R. 1990. Les isotopes de l'hydrogène, du carbone et de l'oxygène dans les minéraux argileux et les eaux de formation. Unpublished Thèse, Institut National Polytechnique de Lorraine, Nancy- France.

Trivedi, J. R., Gopalan, K. \& Valdiya, K. S. 1984. Rb-Sr ages of granitic rocks within the Lesser Himalayan nappes, Kumaun, India. Journal of the Geological Society of India, 25, 641-654.

Vidal, Ph., Bernard-Griffiths ,J., Cocherie, A., Le Fort, P., Peucat, J.J., \& Sheppard, S.M.F. 1984. Geochemical comparison between Himalayan and Hercynian leucogranites. Physic of the Earth.and Planets Interior: 35, 179-90.

Vidal, Ph., Cocherie, A. \& Le Fort, P. 1982. Geochemical investigations of the origin of the Manaslu leucogranite (Himalaya, Nepal). Geochimica et Cosmochimica Acta, 46, 2279-92.

Yeh, H., \& Savin, S.M. 1976. The extent of oxygen isotope exchange between clay minerals and sea water.Geochimica et Cosmochimica Acta, 40, 743-748.

Yokoyama, K., Amano, K., Taira,A., \& Saito, Y. 1990 Mineralogy of silts from the Bengal fan. in Cochran, J.R., Stow, D.A.V. et al., Proceedings of the Ocean Drilling Program, Scientific Results, 116: College Station, TX (Ocean Drilling Program) 59-73.

Yu J., Zhang H., Yu. F \& Liu D. 1984. Oxygen and hydrogen isotopic compositions of meteoric waters in the Eastern part of Xizang. Geochemistry, 3, 93-101. 

Figure captions

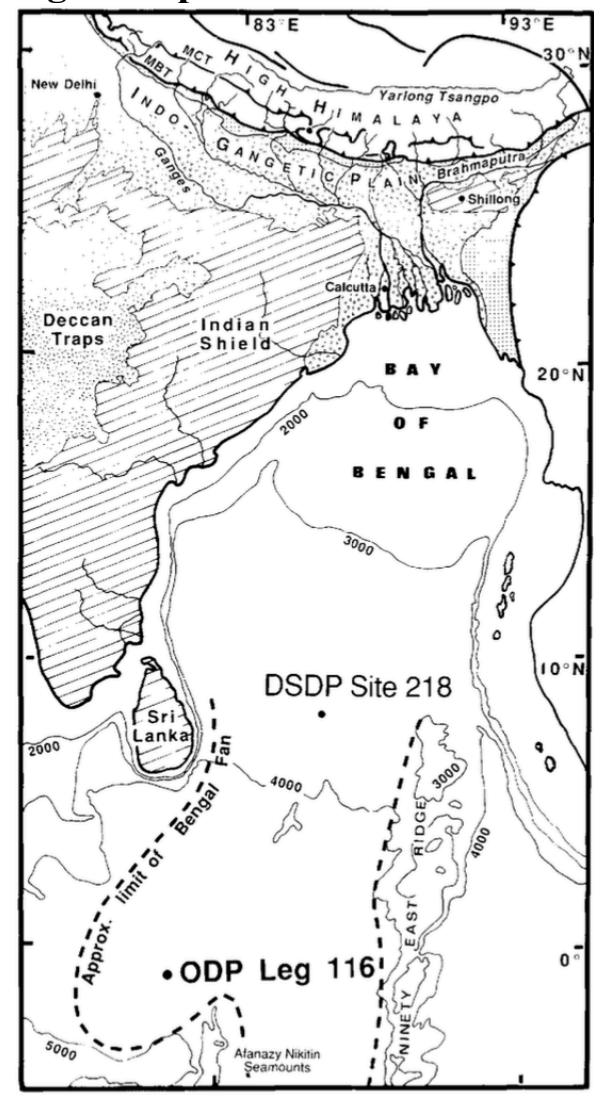

Fig. 1 - Location of the Leg 116 Sites in the the Bengal Basin.

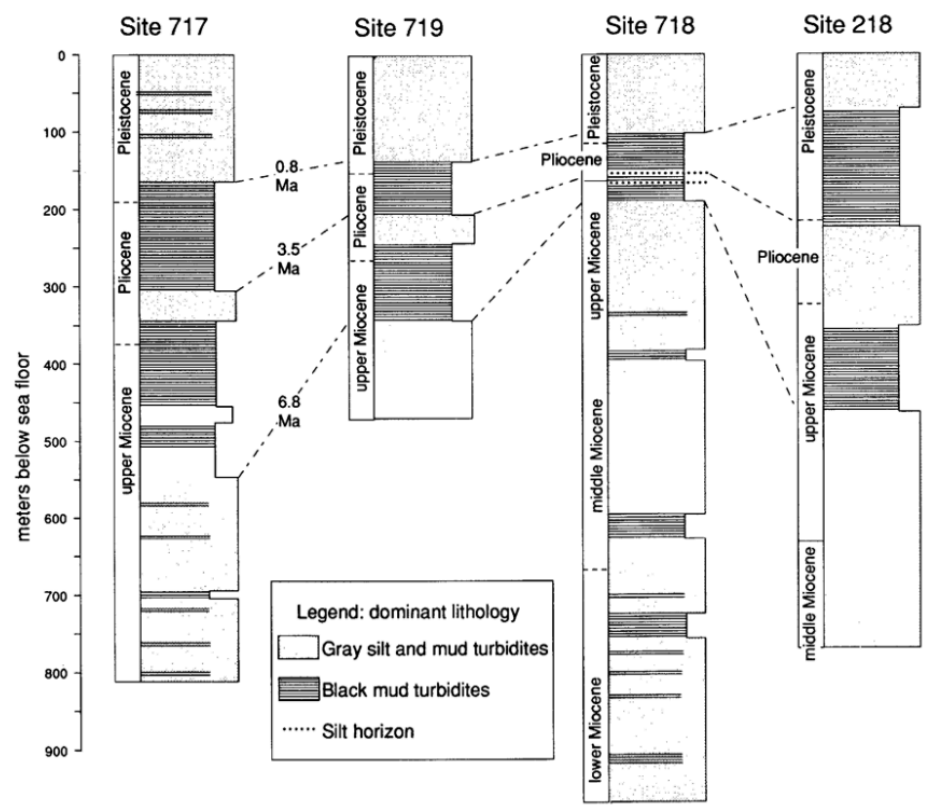

Fig. 2 - Stratigraphic correlation of the Leg 116 Holes 717C, 718C and 719A and Leg 22 Hole 218. Lithologic logs are after Shipboard Scientific Party (1989) and Von der Borch, Sclater et al. 1974. 


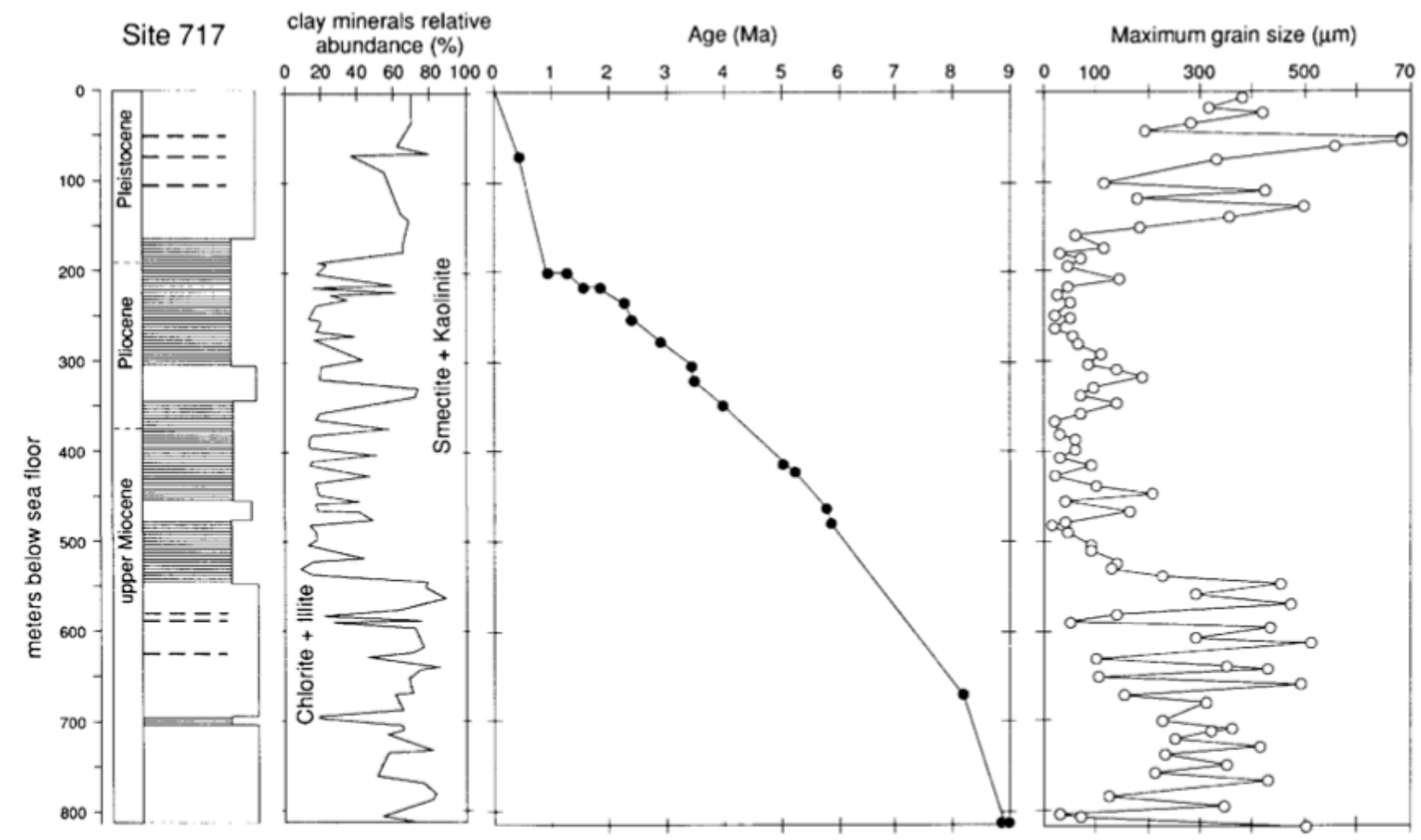

Fig. 3 - Depth versus lithology, chronology (Gartner, 1990), clay mineralogy (Bouquillon et al., 1990) and maximum grain size (Shipboard Scientific Party., 1989) at Site 717. The period dominated by smectite and kaolinite sedimentation is characterized by lower rate of deposition and smaller grain size. 


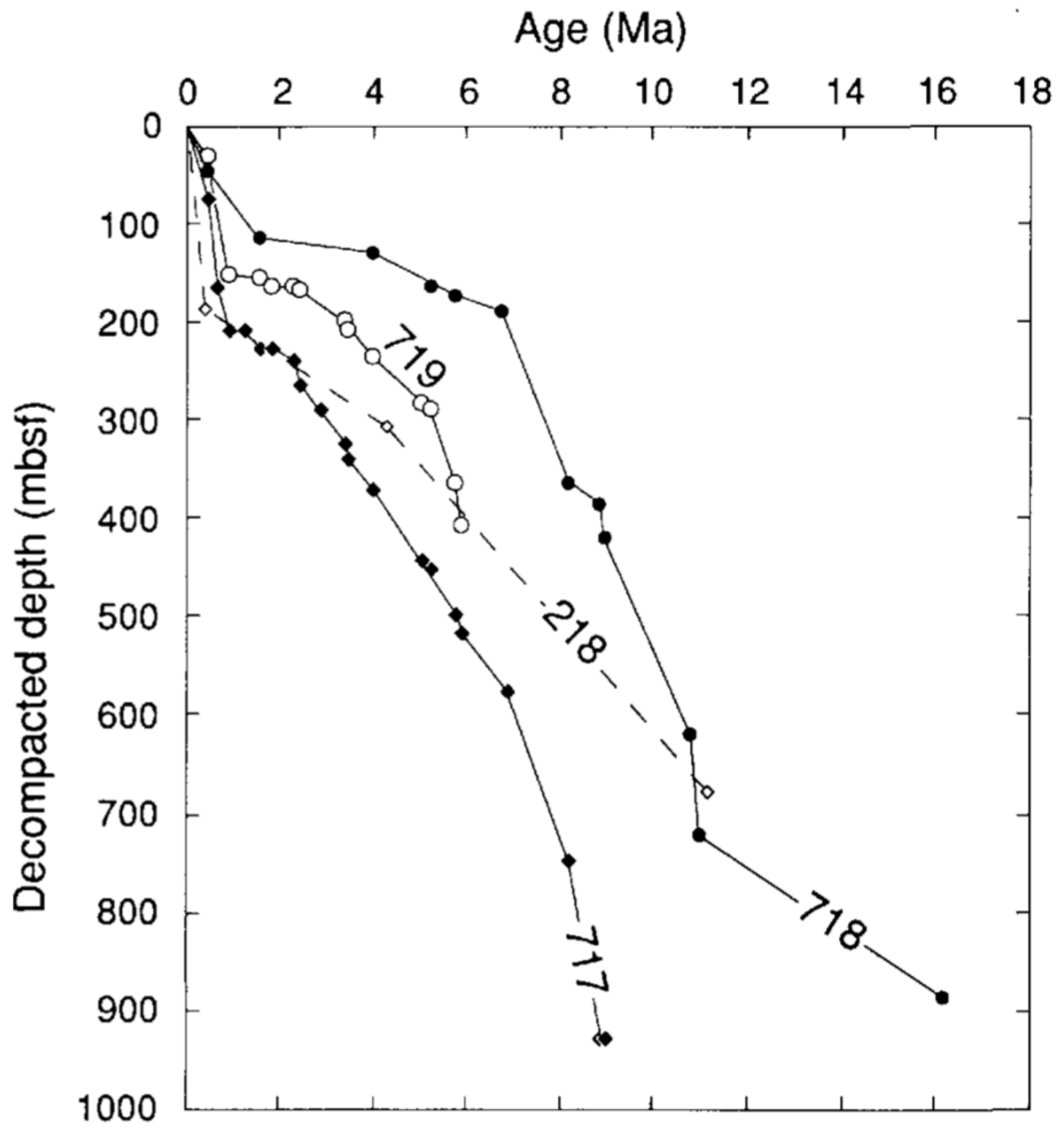

Fig. 4 - Age - depth relations for Holes 218, 717C, 718C, and 719A. Depth is recalculated to correct for the effect of sediment compaction. Biostratigraphic ages are from Gartner et al. (1974) and Gartner (1990). 

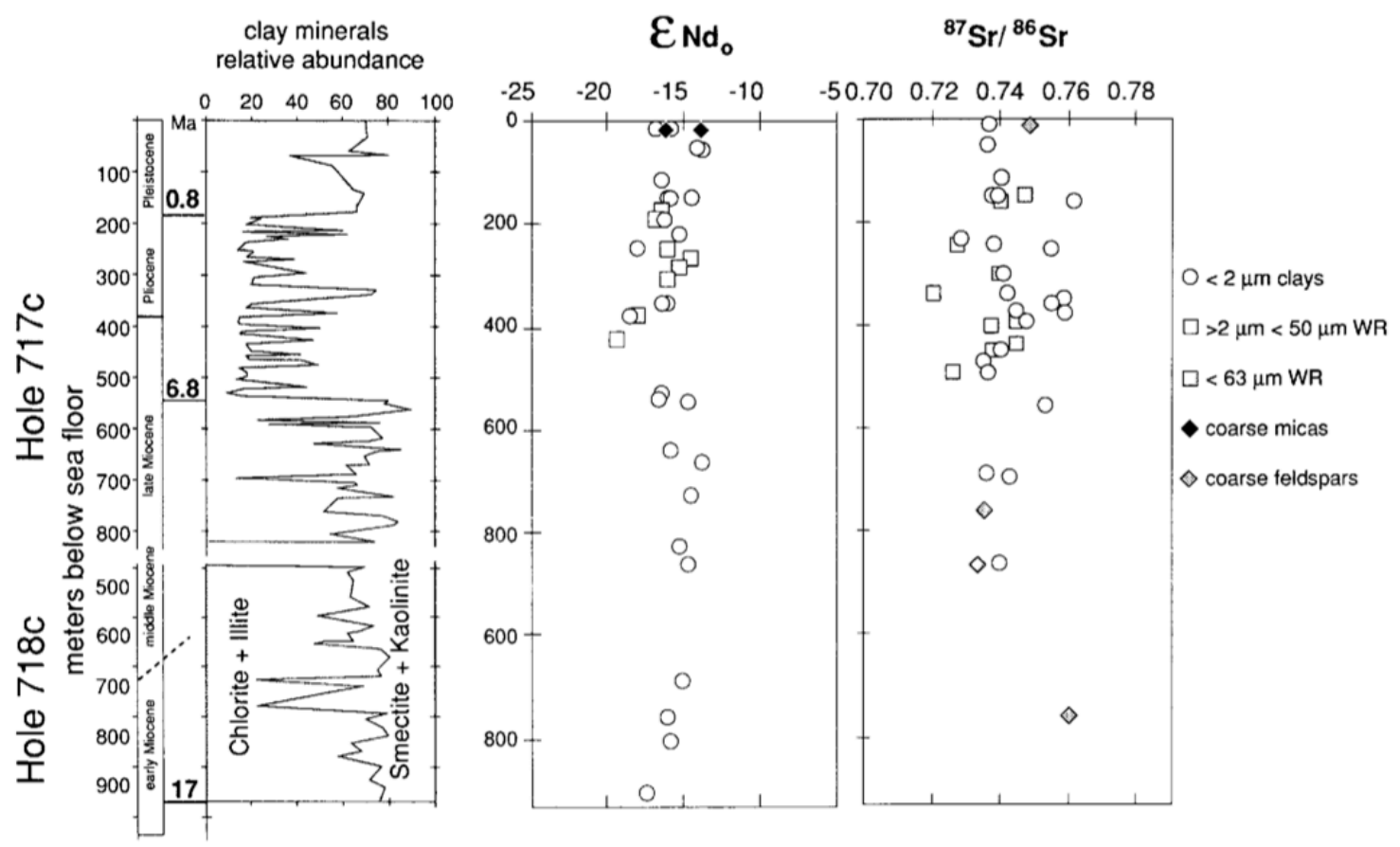

Fig. 5 -

Depth profiles of isotopic composition of $\mathrm{Nd}$ and $\mathrm{Sr}$ for Holes 717C and bottom of 718C. Data are listed in Table 1 or from Bouquillon et al. (1990). Clay mineralogical profiles are simplified after Bouquillon et al. (1990).

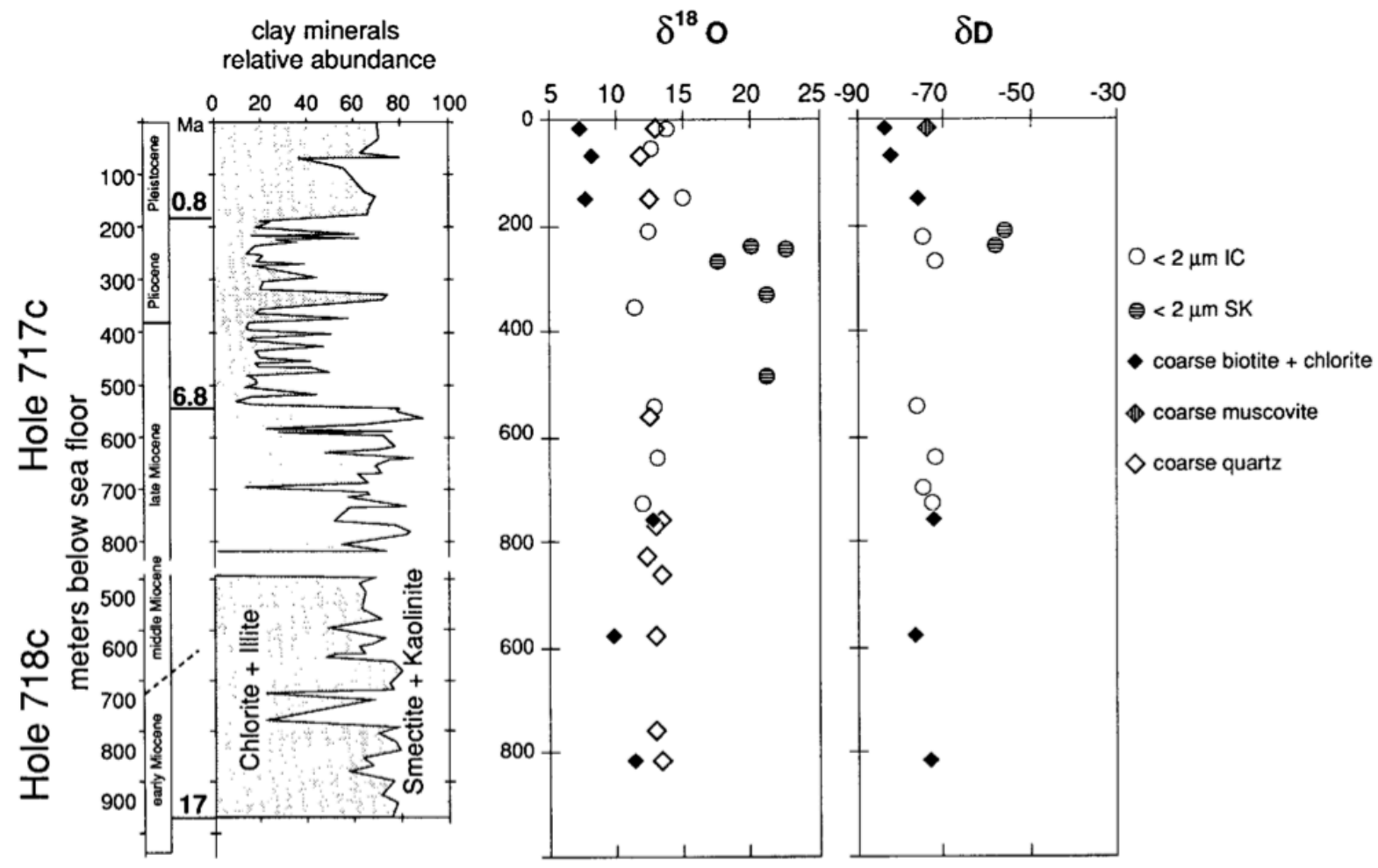

Fig. 6 - Depth profiles of the isotopic composition of $\mathrm{O}$ and $\mathrm{H}$ for Holes 717C and bottom of 718C. Data are listed in Table 1 or from Bouquillon et al. (1990). Clay mineralogical profiles are simplified after Bouquillon et al. (1990). 

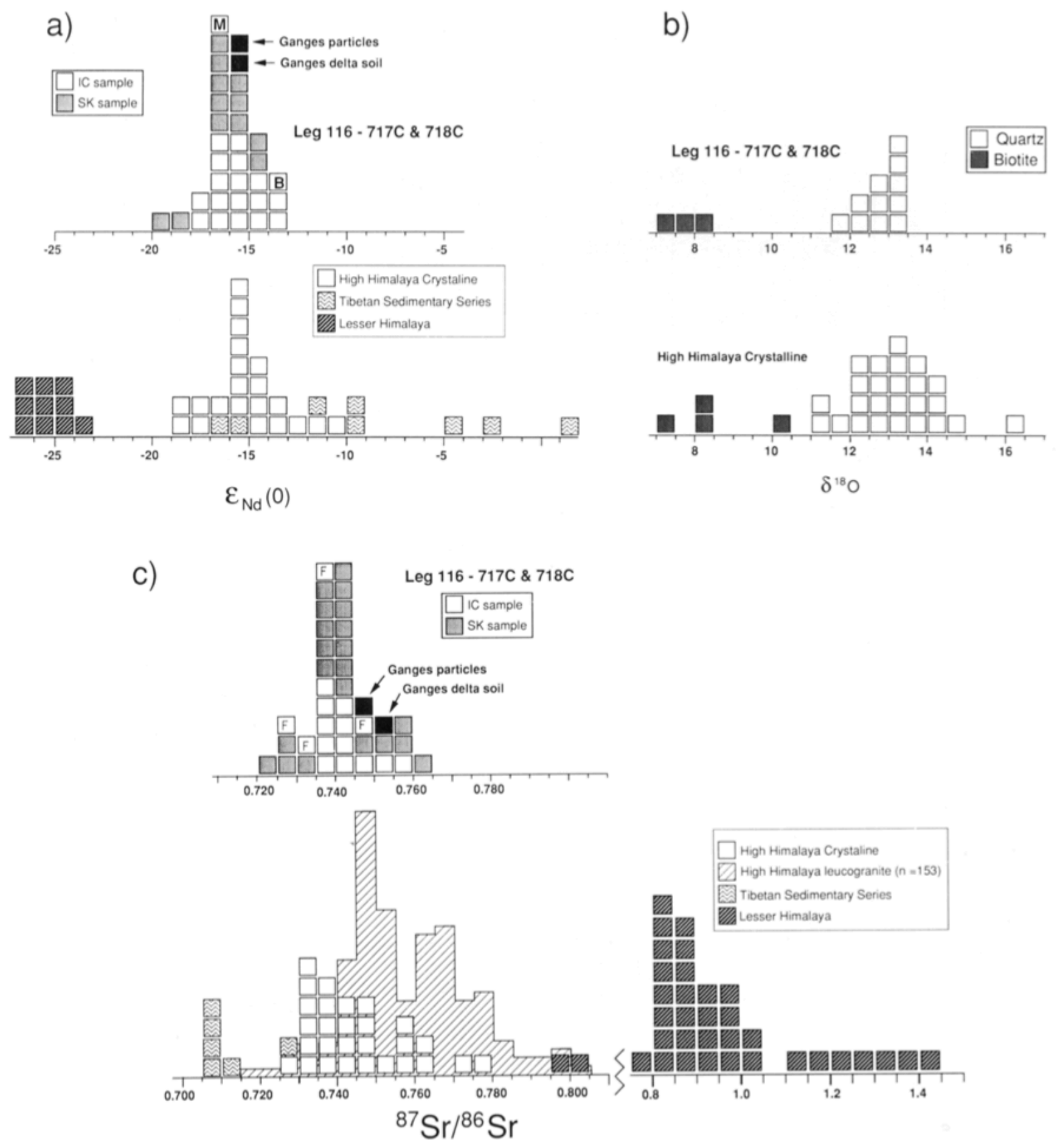

Fig. 7 - Histograms of Nd-, O- and Sr-isotope data of the Leg 116 sediments compared to the Himalayan formations. Average values are similar for the HHC and the Leg 116 samples. a) Nd isotope data, $\mathrm{B}, \mathrm{M}$ represent the values of the coarse biotite+chlorite, and the coarse muscovite separated from sample (116-717C-2H-01,02). b) Oxygene isotope data. c) Sr isotope data, F represents values of coarse feldspar separates. Data are from Table 1 and 2 and: Blattner et al. (1983), Dietrich and Gansser (1981), Deniel et al. (1986 \& 1987), France-Lanord et al. (1988), France-Lanord and Le Fort, (1988), France-Lanord and Scaillet (1989), Goldstein (1988), Goldstein et al. (1984), Parrish et al. (1992), Scaillet et al., (1990), Trivedi et al., (1984), Vidal et al. (1982 \& 1984). 

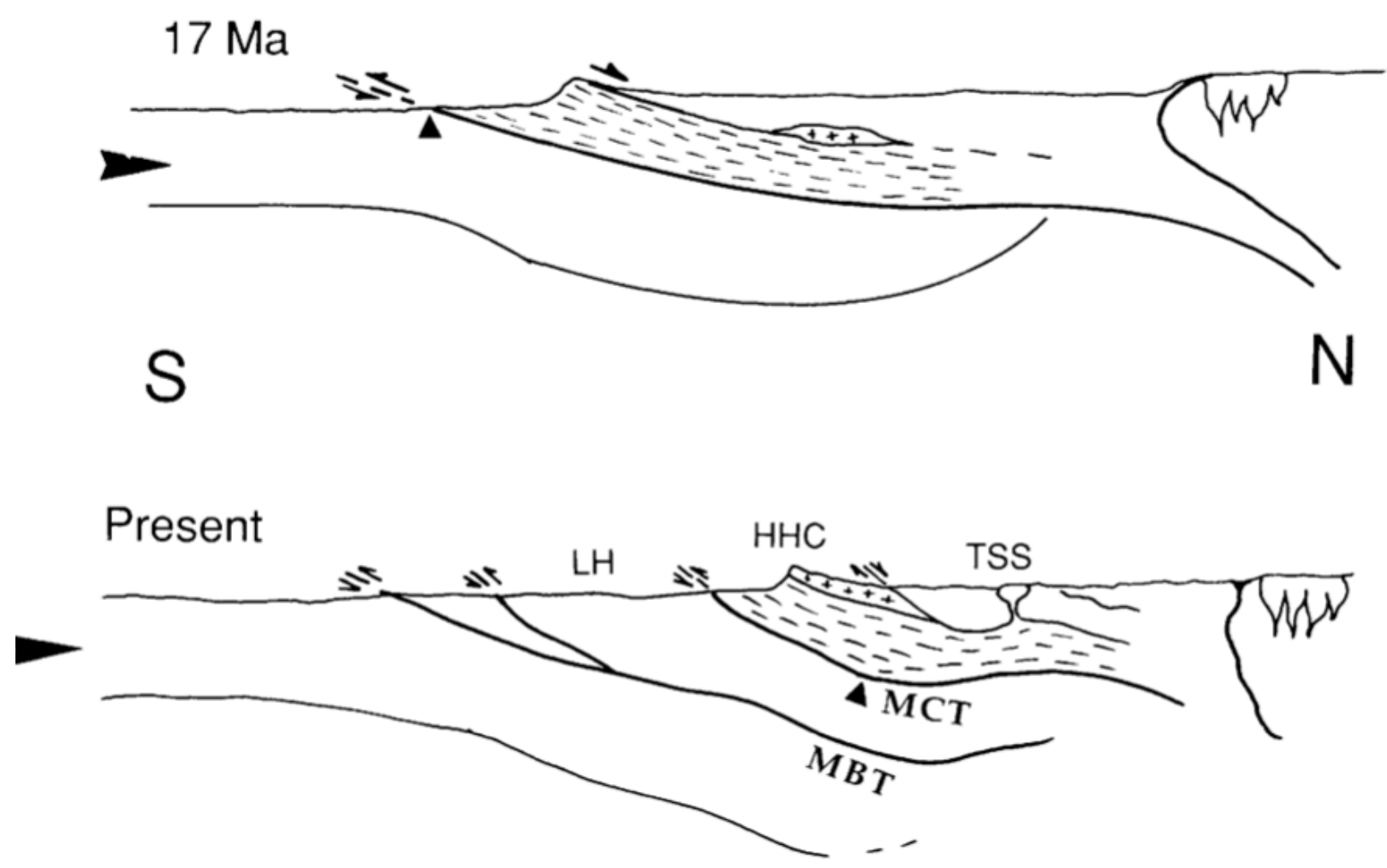

$50 \mathrm{~km}$

Fig. 8 - Schematic cross-section of the Himalaya at $17 \mathrm{Ma}$ and the present day. Thrusting has maintained high elevation in the HHC, while normal faulting has continuously removed the HHSS to the north. This scheme satisfies the requirement that the HHC has been exposed to rapid erosion since the early Miocene, while the HHSS has contributed little to the sediment flux. The black triangle represent a point in the Lesser Himalaya. 
Table $1-\mathrm{H}, \mathrm{O}, \mathrm{Sr}$ and $\mathrm{Nd}$ isotope data and relative abundances of clay minerals on Leg 116 sediments.

mbsf $\varnothing \mathrm{dD} \mathrm{H2O}+\mathrm{d} 180 \mathrm{Rb} \quad \mathrm{Sr} \quad 87 \mathrm{Sr} / 86 \mathrm{Sr}$ 87Rb/86Sr $143 \mathrm{Nd} / 144 \mathrm{Nd} \quad \pm$ eNd(0) Sm Nd Relative abundance of clay in $<2 \mu \mathrm{m}$
$<\varnothing \mu \quad \%$ \% $\%$ ppm ppm
ppm ppm
chlorite
illite int smectite kaolinite

Leg 116 Hole $717 \mathrm{C}$

15.82

$\begin{array}{llll}14 & 232 & 91 & 0.73723\end{array}$

7.39

$\begin{array}{lll}0.511824 \quad 30 & -15.9\end{array}$

2

$79 \quad 0.7381$

$7 X-1(85-86) \quad 56.4 \quad 2$

13

$\begin{array}{lllll}0.511774 & 26 & -16.8 & 6.4 & 32.5\end{array}$

$15 X-2(49-50) \quad 114.5 \quad 2$

$\begin{array}{lll}209 \quad 82 & 0.74048\end{array}$

$\begin{array}{lllll}0.511929 & 17 & -13.8 & 6.5 & 32.9\end{array}$

$\begin{array}{lll}0.511893 \quad 23 & -14.5\end{array}$

$\begin{array}{lllll}0.511817 & 27 & -16 & 7.9 & 40.7\end{array}$

$20 X-1(76-77) \quad 151.3 \quad 2$

0.73791

$\begin{array}{lllll}0.511832 & 28 & -15.8 & 6.5 & 33.2\end{array}$

16

$\begin{array}{llll}41 & 18 & 20 & 5\end{array}$

$\begin{array}{llll}159 & 251 & 0.74731 & 1.83\end{array}$

$21 X-3(34-35) \quad 163.3 \quad 50$

$\begin{array}{llll}126 & 208 & 0.74064 & 1.75\end{array}$

0.76224

$\begin{array}{crrrr}0.5118 & 25 & -16.4 & & \\ 0.511776 & 12 & -16.8 & & \\ 0.511806 & 18 & -16.2 & 5.7 & 27.9\end{array}$

\section{3}

22X-4 (100-101) $175<63$

$24 X-4(66-67) \quad 193.7<63$

$\begin{array}{lllll}0.511806 & 18 & -16.2 & 5.7 & 27.9\end{array}$

$\begin{array}{lllll}0.511855 & 22 & -15.3 & 3.5 & 18.4\end{array}$

$\begin{array}{lccccccccc}27 X-4(70-71) & 223.7 & 2 & -74 & 5.6 & 13 & & & & \\ 28 X-6(19-20) & 235.7 & 2 & & & & & 40 & 0.72798 & \\ 29 X-5(70-71) & 242.7 & \text { WR } & -57 & 5.4 & 20 & & & & \\ 30 X-1(116-117) & 246.7 & 2 & & 23 & & & 0.73851 & \\ & & 50 & & & 78 & 131 & 0.72791 & 1.72\end{array}$

$30 X-3(20-21) \quad 248.7<63$

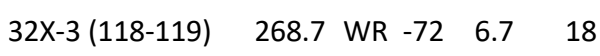

$\begin{array}{lllll}0.511815 & 13 & -16.1 & & \\ 0.511898 & 26 & -14.5 & 5 & 24\end{array}$

$\begin{array}{cccc}12 & 13 & 62 & 10 \\ 10 & 13 & 62 & 13 \\ 8 & 10 & 70 & 10\end{array}$

$\begin{array}{llll}8 & 131 & 0.72791 & 1.72\end{array}$

0.511898

$26-14.5$ 


\begin{tabular}{|c|c|c|c|c|}
\hline $34 X-2$ (76-77) & 285.8 & $<63$ & & \\
\hline \multirow[t]{2}{*}{$35 X-6(28-29)$} & 301.4 & \multicolumn{3}{|l|}{2} \\
\hline & & \multicolumn{3}{|l|}{50} \\
\hline $36 X-3$ (136-137) & 306.9 & \multicolumn{3}{|c|}{$<63$} \\
\hline \multirow[t]{2}{*}{$40 X-2(90-91)$} & 342.9 & \multicolumn{3}{|l|}{2} \\
\hline & & \multicolumn{3}{|l|}{50} \\
\hline $40 X-6(30-31)$ & 348.3 & \multicolumn{3}{|l|}{2} \\
\hline \multirow[t]{2}{*}{ 41X-CC (33-34) } & 359.2 & \multicolumn{3}{|l|}{2} \\
\hline & & \multicolumn{3}{|l|}{2} \\
\hline $43 X-5(100-101)$ & 376 & \multicolumn{3}{|l|}{2} \\
\hline $44 X-2(80-81)$ & 380.8 & \multicolumn{3}{|l|}{2} \\
\hline & & \multicolumn{3}{|l|}{50} \\
\hline \multirow[t]{2}{*}{$45 X-7(4-5)$} & 397 & \multicolumn{3}{|l|}{2} \\
\hline & & \multicolumn{3}{|l|}{50} \\
\hline $46 X-3(39-40)$ & 400.9 & \multicolumn{3}{|c|}{$<63$} \\
\hline $49 X-2(40-41)$ & 427.9 & \multicolumn{3}{|c|}{$<63$} \\
\hline 50X-1 (141-142) & 436.9 & \multicolumn{3}{|l|}{50} \\
\hline $51 X-4(120-121)$ & 450.7 & \multicolumn{3}{|l|}{2} \\
\hline & & \multicolumn{3}{|c|}{50} \\
\hline $54 X-1(59-60)$ & 474.1 & \multicolumn{3}{|l|}{2} \\
\hline \multirow[t]{2}{*}{$55 X-C C(45-46)$} & 492.1 & 2 & & \\
\hline & & \multicolumn{3}{|c|}{50} \\
\hline 59X-6 (57-58) & 529.1 & 2 & & \\
\hline $61 X-1$ (115-116) & 541.2 & 2 & -76 & 2.2 \\
\hline 71X-4 (125-126) & 640.8 & 2 & -71 & 2.2 \\
\hline $75 X-4(25-26)$ & 679.3 & 2 & & \\
\hline 77X-5 (132-133) & 699.3 & 2 & & \\
\hline
\end{tabular}

$\begin{array}{lll}0.511858 & 13 & -15.2\end{array}$

0.74067

$\begin{array}{llll}105 & 114 & 0.74008 & 2.66\end{array}$

$\begin{array}{lllll}21 & 72 & 24 & 0.7422 & 8.58\end{array}$

$\begin{array}{lllll}77 & 138 & 0.72086 & 1.62\end{array}$

$\begin{array}{lllll}64 & 25 & 0.75877 & 7.34\end{array}$

$\begin{array}{lll}12 & 73 & 0.75512\end{array}$

$\begin{array}{llll}62 & 13 & 0.74476 & 14.1\end{array}$

0.75891

$\begin{array}{llll}56 & 15 & 0.74836 & 10.66\end{array}$

0.745

$\begin{array}{llll}63 & 43 & 0.73729 & 4.26\end{array}$

$\begin{array}{llll}139 & 127 & 0.74479 & 3.16\end{array}$

0.74058

$\begin{array}{llll}116 & 120 & 0.7378 & 2.8\end{array}$

$\begin{array}{llll}56 & 29 & 0.7354 & 5.67\end{array}$

$\begin{array}{lllll}21 & 75 & 26 & 0.73665 & 8.45\end{array}$

$\begin{array}{lllll}98 & 129 & 0.72685 & 2.19\end{array}$

$\begin{array}{lllll}0.511798 & 34 & -16.4 & 4.8 & 22.9\end{array}$

$\begin{array}{llllll}0.511788 & 30 & -16.6 & 5.1 & 25.8\end{array}$

$\begin{array}{lllll}0.511828 & 23 & -15.8 & 5 & 27.2\end{array}$

$0.511796 \quad$ \#\#\# -16.4

$\begin{array}{lllll}0.511818 & 34 & -16 & 7.2 & 37.2\end{array}$

$\begin{array}{lll}0.511719 \quad 19 & -17.9\end{array}$

$0.51165 \quad 13 \quad-19.3$

$\begin{array}{cccc}8 & 13 & 55 & 20 \\ 11 & 9 & 61 & 17 \\ 11 & 9 & 61 & 17 \\ 9 & 15 & 57 & 18 \\ 7 & 15 & 57 & 18 \\ 7 & 15 & 57 & 18 \\ 7 & 12 & 65 & 13\end{array}$

$0.511689 \quad 22 \quad-18.5$

$\begin{array}{ll}56 & 0.73628\end{array}$

0.74333

\section{4}

2

2

2

2

3

3

3
2

2
3

3

2

2

2

3

3

3

3

22

25

$77 X-5(132-133) \quad 699.3 \quad 2$

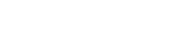




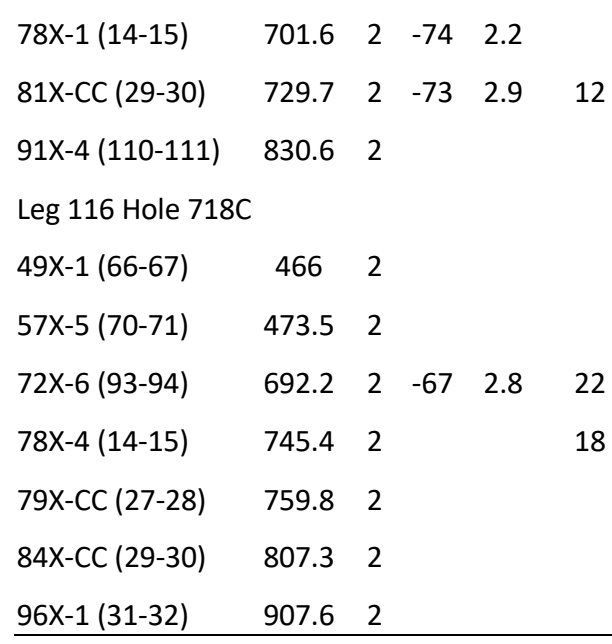

\begin{tabular}{cccccccccc}
0.511895 & 29 & -14.5 & 4.7 & 23.9 & 25 & 50 & 20 & 2 & 3 \\
0.511855 & 32 & -15.3 & 7.9 & 41.1 & 27 & 41 & 10 & 19 & 3 \\
0.511891 & 17 & -14.6 & 9.1 & 47.4 & 22 & 39 & 14 & 18 & 7 \\
0.511857 & 26 & -15 & 4.9 & 25.2 & & & & & \\
& & & & & 2 & 8 & 10 & 55 & 25 \\
0.511805 & 24 & -16 & 5.6 & 28.8 & 17 & 10 & 9 & 50 & 25 \\
0.511821 & 23 & -15.9 & 5.4 & 28 & 27 & 56 & 12 & 10 & 5 \\
0.511744 & 44 & -17.4 & 5 & 25.7 & 25 & 47 & 13 & 8 & 5 \\
& & & & & & 47 & 12 & 10 & 6 \\
\hline
\end{tabular}

Data in italics and most X-ray determinations of clay are from Bouquillon et al. (1990).

$87 \mathrm{Sr} / 86 \mathrm{Sr}$ normalized to $86 \mathrm{Sr} / 88 \mathrm{Sr}=0.1194$. Average value of NBS 987 during the period of analysis was 0.710197

$143 \mathrm{Nd} / 144 \mathrm{Nd}$ normalized to $146 \mathrm{Nd} / 144 \mathrm{Nd}=0.7219$. Average value of LaJolla Nd during the period of analysis was $0.511847 \mathrm{~d} 180$ of NBS $28=9.60 \%$ o 
Table 2 - Sr and Nd isotope data for soil from Bangladesh and rocks from the Lesser Himalaya, High Himalaya Sedimentary series

\begin{tabular}{|c|c|c|c|c|c|c|c|c|c|c|c|}
\hline & $\begin{array}{l}\text { Type } \\
<\varnothing \mu\end{array}$ & $\begin{array}{c}\mathrm{Rb} \\
\mathrm{ppm}\end{array}$ & $\begin{array}{c}\mathrm{Sr} \\
\mathrm{ppm}\end{array}$ & $87 \mathrm{Sr} / 86 \mathrm{Sr}$ & $87 \mathrm{Rb} / 86 \mathrm{Sr}$ & $143 \mathrm{Nd} / 144 \mathrm{Nd}$ & \pm & Eps 0 & $\begin{array}{l}\text { Sm } \\
\text { ppm }\end{array}$ & $\begin{array}{l}\mathrm{Nd} \\
\mathrm{ppm}\end{array}$ & $\begin{array}{l}\text { TDM } \\
\text { Ga }\end{array}$ \\
\hline \multicolumn{12}{|l|}{ Soil from the Ganges delta } \\
\hline Batra series & $<2 \mu \mathrm{m}$ & & 32 & 0.75236 & 22.18 & 0.511855 & 15 & -15.3 & 4.7 & 23.6 & \\
\hline \multicolumn{12}{|c|}{ High Himalaya Sedimentary Series } \\
\hline NA 178 Jurassic schist & W.R. & & & & & 0.511795 & 28 & -16 & 4 & 20.3 & 2 \\
\hline NA 181 Cretaceous (volcaniclastic) & W.R. & & & & & 0.512405 & 28 & -4.5 & 12.6 & 59 & 1.26 \\
\hline 8728 Cretaceous & W.R. & 42 & 61 & 0.71227 & 1.904 & 0.512093 & 13 & -10.6 & 9.1 & 45.5 & 1.53 \\
\hline 8732 Trias & W.R. & 19 & 45 & 0.70899 & 1,19 & 0,511824 & 17 & -15.9 & 3.6 & 18.6 & 1.93 \\
\hline LA 194 Indus Margin & W.R. & 11 & 299 & 0.70981 & 0.103 & 0.511883 & 9 & -14.7 & 5.91 & 33.2 & 1.64 \\
\hline LA 158 Indus Marginn & W.R. & 96 & 50 & 0.72903 & 5.289 & 0.512046 & 37 & -11.6 & 5 & 23.2 & 1.77 \\
\hline 251 Suture Ladak & W.R. & 7 & 662 & 0.70762 & 0.027 & 0.512313 & 34 & -6.3 & 1.6 & 6.4 & 1.68 \\
\hline Suture Ladak & W.R. & 44 & 258 & 0.70606 & 0.469 & 0.51258 & 24 & -1.1 & 3 & 13.9 & 0.88 \\
\hline \multicolumn{12}{|l|}{ Lesser Himalaya } \\
\hline AP 346Kunchha pelites & W.R. & 143 & 11.1 & 1.6809 & 38.07 & 0.511397 & 28 & -24 & 8.08 & 44 & 2.52 \\
\hline AP 385Kunchha pelites & W.R. & 286 & 63 & 1.0301 & 13.48 & 0.511331 & 25 & -25 & 6.58 & 36.6 & 2.6 \\
\hline
\end{tabular}

forData in italic are from France-Lanord and Le Fort, 1988 and Bouquillon et al., 1990.

see table 1 for analytical parameters 